

\section{The Impact of Ethanol Blending on U.S. Gasoline Prices}

McKinsey and Company, Inc provided analytic and drafting support in preparation of this report, with technical oversight provided by Bill Babiuch, NREL Technical Monitor. Services were supplied under subcontract number KACX-8-88316-01.

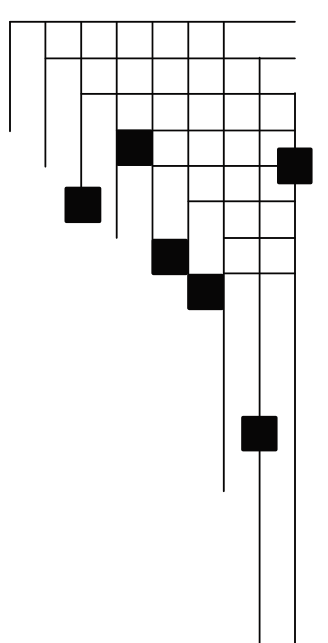


This publication was reproduced from the best available copy Submitted by the subcontractor and received no editorial review at NREL

\section{NOTICE}

This report was prepared as an account of work sponsored by an agency of the United States government. Neither the United States government nor any agency thereof, nor any of their employees, makes any warranty, express or implied, or assumes any legal liability or responsibility for the accuracy, completeness, or usefulness of any information, apparatus, product, or process disclosed, or represents that its use would not infringe privately owned rights. Reference herein to any specific commercial product, process, or service by trade name, trademark, manufacturer, or otherwise does not necessarily constitute or imply its endorsement, recommendation, or favoring by the United States government or any agency thereof. The views and opinions of authors expressed herein do not necessarily state or reflect those of the United States government or any agency thereof.

Available electronically at http://www.osti.gov/bridge

Available for a processing fee to U.S. Department of Energy and its contractors, in paper, from:

U.S. Department of Energy

Office of Scientific and Technical Information

P.O. Box 62

Oak Ridge, TN 37831-0062

phone: 865.576 .8401

fax: 865.576 .5728

email: mailto:reports@adonis.osti.gov

Available for sale to the public, in paper, from:

U.S. Department of Commerce

National Technical Information Service

5285 Port Royal Road

Springfield, VA 22161

phone: 800.553 .6847

fax: 703.605.6900

email: orders@ntis.fedworld.gov

online ordering: http://www.ntis.gov/ordering.htm 


\section{Table of Contents}

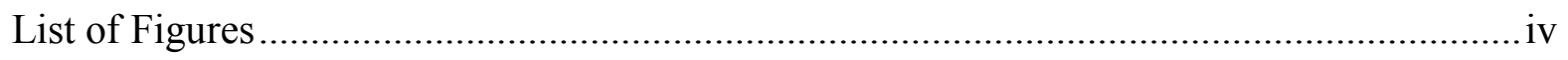

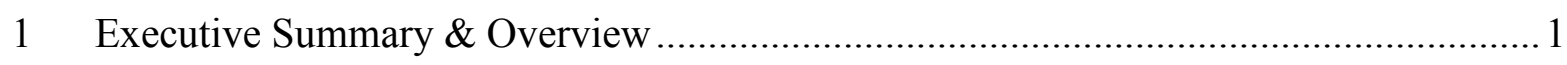

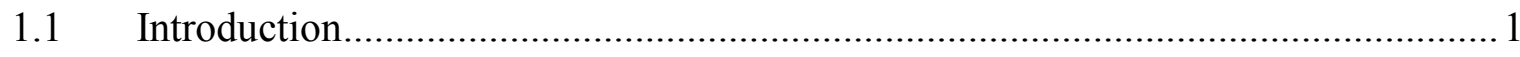

1.2 Overview of Recent Research and Specific Approach of This Study ....................... 2

$1.3 \quad$ Key Assumptions .............................................................................................

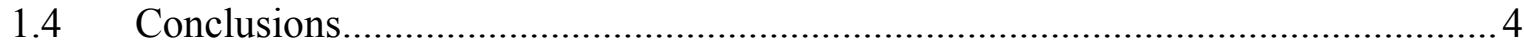

2 Reducing Gasoline Prices at the Pump …………................................................... 6

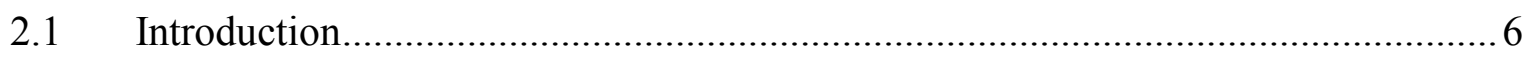

2.2 Cheaper Blendstock at Current Corn and Oil Prices ……….................................. 7

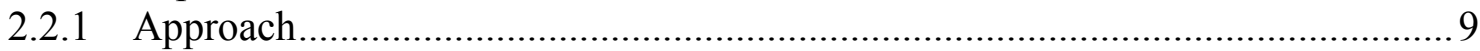

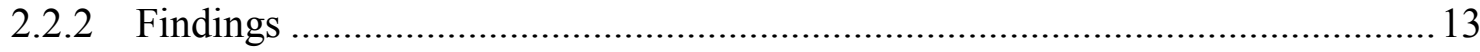

2.3 Best Oxygenate in Reformulated Gasoline Markets............................................... 14

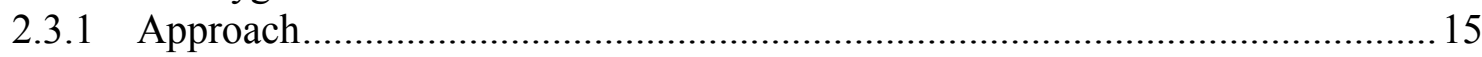

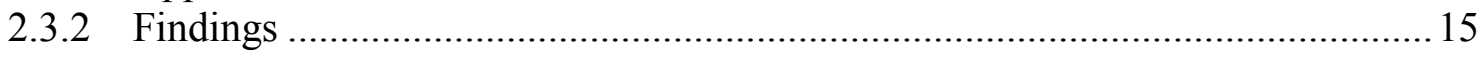

2.4 Increased Fossil Gasoline Yield per Barrel of Oil ................................................. 16

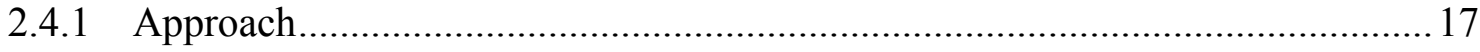

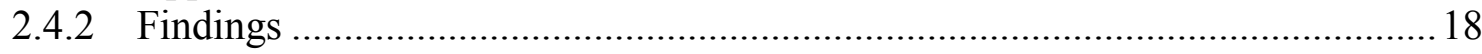

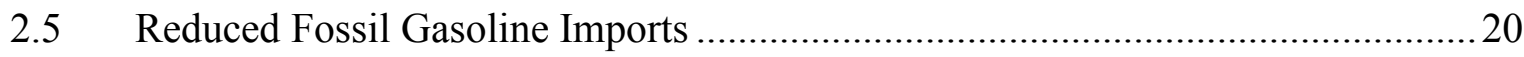

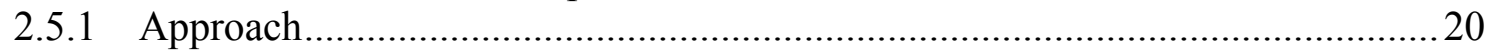

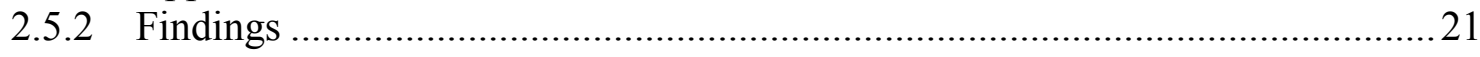

2.6 Relative Fossil Gasoline Overcapacity ………….............................................22

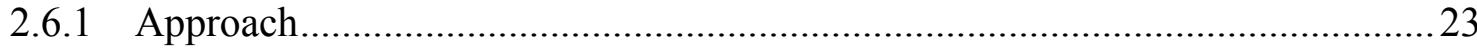

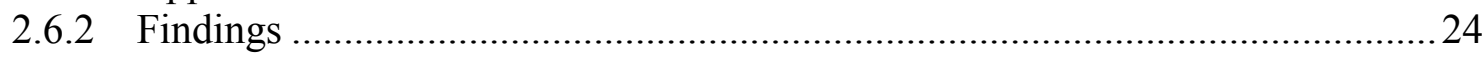

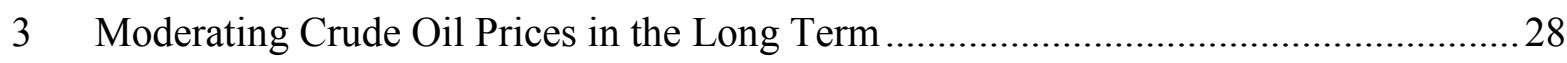

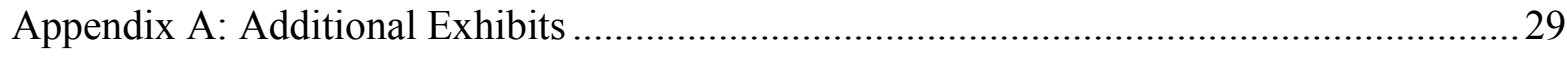

Appendix B: Ethanol pricing mechanisms and the substitution effect.....................................30 


\section{List of Figures}

Figure 1. Overview of other 2008 research on the impact of ethanol blending on U.S. retail gasoline prices ............................................................................................

Figure 2. Impact of ethanol blending on retail gasoline prices ...........................................

Figure 3. Impact of ethanol blending on gasoline production cost ...................................... 8

Figure 4. Sufficient ethanol must be available to the blenders in the market for cost reduction to be passed through to drivers .......................................................... 9

Figure 5. Today's U.S. ethanol supply curve ................................................................... 11

Figure 6. States with RFG markets and ethanol penetration in states without gasoline ....... 12

Figure 7. Impact of the substitution effect on the price of a gallon of E10

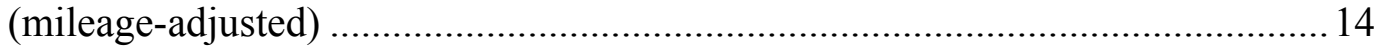

Figure 8. Impact of ethanol blending on volume of fossil gasoline components.................. 17

Figure 9. Output of the Refinery Linear Programming Model ........................................... 19

Figure 10. 2008 U.S. fossil gasoline supply curve in spring and summer .............................21

Figure 11. Fossil gasoline supply and demand during summer months ................................22

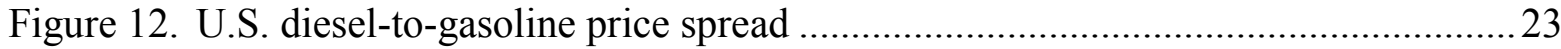

Figure 13. In response to rapidly growing global diesel demand, refineries worldwide are maximizing their diesel production ..................................................................25

Figure 14. Cumulative global gasoline supply capacity additions since $2005 \ldots \ldots \ldots \ldots \ldots \ldots \ldots \ldots . . .26$

Figure A. Overview of end-to-end gasoline production in U.S ........................................2

Figure B. Broader economic impact of ethanol blending ....................................................2 


\section{Executive Summary \& Overview}

\subsection{Introduction}

Ethanol derived from plant material, also called bio-ethanol, is used as a blendstock for gasoline and as an alternative source of transportation fuel in many countries. Today, almost seventy percent of gasoline at the pump in the U.S. contains ethanol ${ }^{1}$. Most of the ethanol is sold in a gasoline blend of 10\% ethanol and $90 \%$ fossil gasoline (called E10 gasoline). E10 is sold at the pump as regular gasoline ${ }^{2}$, except in California, where the maximum ethanol concentration allowed in regular gasoline at the time of the study was 5.7 percent $^{3}$. A very small portion of ethanol in the U.S. is used to make E85 (85\% ethanol) gasoline for flexible fuel vehicles. Exhibit A in the appendix provides an overview of the end-to-end U.S. gasoline supply.

Most of the ethanol consumed in the U.S. is corn-based ethanol produced domestically, and about $7 \%$ is sugarcane-based ethanol, imported primarily from Brazil. ${ }^{4}$ Cellulosic ethanol, produced from cellulosic materials like corn stover, switchgrass and woodchips, is expected to become economically attractive in the near future, as production technologies mature and production capacity is scaled up.

The global volume of ethanol used as a transportation fuel has more than tripled since 2000, driven primarily by strong demand from the U.S. The rapid growth in United States ethanol consumption has been driven at least in part by U.S. energy policy, which stimulates the use of ethanol through mandates and subsidies. The 2007 Energy Independence and Security Act (EISA) extended the Renewable Fuel Standard, stipulating minimum volumes of ethanol to be used in the U.S. for each year until 2022. Certain regional and local markets, such as the state of Minnesota, also mandate ethanol blending in gasoline. Furthermore, the U.S. subsidizes ethanol blending by providing a credit for each gallon of ethanol blended. In May 2008, Congress passed Farm bill HR-2419, which included an extension of the ethanol subsidy, but lowered it from 51 to 45 cents per gallon for corn-based ethanol.

This study assesses the impact of ethanol blending on gasoline prices in the US today and the potential impact of ethanol on gasoline prices at higher blending concentrations $(10 \%, 15 \%$ and $20 \%$ of the total U.S. gasoline consumption).

1 The United States consumes more ethanol for transportation than any other country, although Brazil has the highest level of ethanol penetration, with ethanol providing more than 40 percent of its light vehicle fuel.

2 By law, gasoline blends up to E10 have to be covered under warranty by every auto manufacturer that sells vehicles in the U.S. Recent tests by the State of Minnesota and the DOE have shown that blends up to E20 do not pose problems for current vehicles or fuel dispensing equipment.

3 California Air Resources Board Rules that prescribe the predictive gasoline blending model to be used by refineries effectively limited ethanol concentration to $5.7 \%$. However, a new predictive model, approved in September 2008, allows for higher ethanol concentrations.

4 The Caribbean Basin Initiative (CBI) provides a tariff exemption for imports from Caribbean countries, up to a volume of 7 percent of U.S. ethanol consumption. Most of the ethanol imported through the CBI is produced in Brazil and passes through Caribbean countries to be processed before arrival in the U.S. Above this volume, the tariff on ethanol imports is 54 cents per gallon plus an ad-valorem duty of $2.5 \%$. 


\subsection{Overview of Recent Research and Specific Approach of This Study}

Recent research on the impact of ethanol on average U.S. gasoline prices today has shown effects ranging from 20-35 cents per gallon (earlier study from Department of Energy and Department of Agriculture) to 50 cents per gallon of gasoline (Merrill Lynch). Other studies focused on the past or future impact of ethanol on gasoline prices, or on the impact on gasoline prices in a specific state. Exhibit 1 gives an overview of recent research on the topic.

\begin{tabular}{|c|c|c|c|}
\hline \multicolumn{4}{|c|}{$\begin{array}{l}\text { OVERVIEW OF OTHER } 2008 \text { RESEARCH ON THE IMPACT OF } \\
\text { ETHANOL BLENDING ON U.S. RETAIL GASOLINE PRICES }\end{array}$} \\
\hline & Conclusion & Methodology & Date \\
\hline \multirow[t]{2}{*}{ LEGC } & $\begin{array}{l}\text { E10 gasoline in Missouri will be } 7 \phi \\
\text { per gallon cheaper than conventional } \\
\text { gasoline over next } 10 \text { years }\end{array}$ & $\begin{array}{l}\text { Substitution effect calculated based on } 2008 \text { AEO } \\
\text { gasoline and ethanol price projections }\end{array}$ & April 2 \\
\hline & $\begin{array}{l}\text { Ethanol blending at E10 in South } \\
\text { Dakota saved consumers } 11 \phi \text { per } \\
\text { gallon in the period March } 2007- \\
\text { March } 2008\end{array}$ & $\begin{array}{l}\text { Substitution effect calculated based on gasoline and } \\
\text { ethanol prices }\end{array}$ & June 26 \\
\hline $\begin{array}{l}\text { lowa State } \\
\text { University }\end{array}$ & $\begin{array}{l}\text { Ethanol blending reduced gasoline } \\
\text { prices on average by } 29 \phi-40 \phi \\
\text { depending on region in U.S., over } \\
1995-2007 \text { period }\end{array}$ & $\begin{array}{l}\text { Regression analysis of gasoline price with ethanol } \\
\text { production, crude oil and product market conditions, } \\
\text { refinery capacity and utilization, gasoline imports and } \\
\text { seasonality as variables }\end{array}$ & April \\
\hline RFA & $\begin{array}{l}\text { Consumers should be realizing a } 13 \\
\phi \text { saving per gallon by utilizing } E 10 \text { if } \\
\text { refiners are passing through } \\
\text { savings }\end{array}$ & $\begin{array}{l}\text { Substitution effect calculated with May } 30 \text { prices for } \\
\text { ethanol and gasoline }\end{array}$ & June 3 \\
\hline Merrill Lynch & $\begin{array}{l}\text { U.S. retail gasoline prices today } \\
\text { would be } 50 \phi \text { per gallon higher } \\
\text { without ethanol }\end{array}$ & $\begin{array}{l}\text { Assessed impact of ethanol on fossil gasoline supply } \\
\text { demand balance and pricing (methodology not clear) }\end{array}$ & June 6 \\
\hline $\begin{array}{l}\text { U.S. DOE \& } \\
\text { DOA }\end{array}$ & $\begin{array}{l}\text { Without ethanol, today's gasoline } \\
\text { prices would be } 20 \phi \text { to } 35 \phi \text { per } \\
\text { gallon higher }\end{array}$ & $\begin{array}{l}\text { Substitution effect calculated based on current price } \\
\text { differential between ethanol and gasoline; } \\
\text { assessment of impact of ethanol on fossil gasoline price } \\
\text { based on petroleum supply elasticity }\end{array}$ & June 6 \\
\hline
\end{tabular}

Figure 1. Overview of other 2008 research on the impact of ethanol blending on U.S. retail gasoline prices

The majority of studies to date have focused on the benefit derived from current price differentials in the market, with ethanol priced cheaper than fossil gasoline (referred to in this report as the substitution effect, which is covered in Section 2.2). These studies all assess the reduction in gasoline production costs due to ethanol blending. However, they overestimate the impact of the substitution effect on driver economics, because the reduced gasoline production costs do not translate fully into savings for end consumers, for two reasons:

First, this study will show that as blending levels are inconsistent throughout pricing regions, the benefits of reduced gasoline production costs are not necessarily fully passed through to the end consumer in all regions. With supply based economics, in a given region the marginal (or highest cost) producer sets the price that the other producers follow, usually higher than the lowest cost provider. If all of the producers in a region are blending to $10 \%$ and accruing the substitution benefit, then competition will drive the retail 
price down to where the benefit is passed through to the end consumer. In many regions in the U.S. today only some of the producers are blending to $10 \%$, while others are not blending ethanol, and thus not benefiting from the lower cost. These producers will be the marginal producers, and thus set the price in the region. The producers enjoying the lower production cost due to blending ethanol will keep the benefit to themselves and not pass it on to the end consumer (see Section 2.2 for more detail).

Second, all of the studies that we reviewed focused on the savings from ethanol per gallon of gasoline. However, this does not represent the true savings to the driver, as it does not take into account the negative impact on mileage performance resulting from ethanol's lower energy content when compared to unblended gasoline. Indeed, a driver using blended gasoline will have to fill up his car more frequently in order to travel the same distance as he would otherwise with unblended gasoline.

This study takes into account the pricing situation described above, as well as the fact that ethanol's lower energy content results in lower mileage per gallon when compared to unblended gasoline. As this study will show, when these two factors are taken into account, the net impact of the substitution effect can actually be an increase of the mileage-adjusted cost of gasoline for drivers. Ethanol does, however, generate several additional sources of impact to gasoline prices besides the substitution effect. This study provides a more thorough review of the impact of ethanol blending on retail gasoline prices than any of the earlier studies we reviewed.

\subsection{Key Assumptions}

This study assesses the current impact of ethanol on gasoline prices (based on the price environment in the first three quarters of 2008), the potential impact at the current maximum 10 percent allowable U.S. ethanol blending level for regular gasoline, as well as at 15 percent and 20 percent ethanol blending levels. The analysis is based on prevailing market conditions and the current political and economic landscape, which includes the subsidy for ethanol blending in the U.S. ${ }^{5}$ as well as the tariff on ethanol imports. Today's ethanol demand is based on the 9 billion gallon volume mandated by the RFS in 2008, which is slightly below the EIA's March 2008 ethanol consumption projection of 9.1 billion gallons for 2008 .

Pure ethanol has an energy content that is roughly two thirds of that of fossil gasoline. As a result, a gallon of blended gasoline will yield a lower mileage than a gallon of pure fossil gasoline. We used the results of the Oak Ridge National Laboratory's October 2008 report (Effects of Intermediate Ethanol Blends on Legacy Vehicles and Small Non-Road Engines) to account for the reduced fuel economy from ethanol blending. For E10, we used a mileage loss versus E0 of 3.88 percent. For E15 and E20, the mileage losses versus E0 were 5.03 and 7.72 percent, respectively. Throughout the report, we have adjusted for the mileage loss due to ethanol blending. For instance, to calculate the impact of blending ethanol up to $10 \%$ on

5 For this analysis, a subsidy of 51 cents per gallon of ethanol was used for all scenarios. Note that the Farm bill of May 2008 lowered the subsidy to 45 cents. 
the price of gasoline, we compared the wholesale price of a gallon of E0 with the wholesale price of 1.04 gallons of E10 - the driver will have to buy 1.04 gallons of E10 to get the same mileage as he gets from one gallon of E0.

This analysis modeled the impact of ethanol on gasoline prices in a static price environment for different scenarios with specific feedstock price assumptions. The team did not model secondary pricing feedback loops, but confirmed for each effect of ethanol that was modeled that the impact of the secondary feedback loops would be negligible compared to the overall impact of the effect. For instance, when assessing the cost of substituting propanol for ethanol as an oxygenate, the team verified that the increased propanol consumption would not result in a noticeable price increase of its feedstock, naphtha.

This analysis does not advocate one ethanol feedstock over another - achieving higher blending levels economically will likely require a mix of sources for ethanol (U.S. cornbased and cellulosic ethanol, as well as imported sugarcane-based ethanol).

Significant changes to fuel transportation infrastructure, gas stations and vehicle fleet may be required to increase the national ethanol concentration in gasoline to the levels described in this report, and the investments associated with these changes could be very substantial. This analysis did not look into and does not account for any of the changes in infrastructure needed to accommodate the higher ethanol blends. Furthermore, for the purpose of this study, no assumptions were made about the exact composition of the U.S. gasoline fuel supply (e.g. E10 versus E85) that will lead to the higher national blending levels covered by this analysis ${ }^{6}$. The actual split in volume between the different gasoline blends has a significant impact on the type of infrastructure and level of investments that need to happen to achieve the higher national ethanol blending levels.

The analysis does not attempt to draw broader conclusions about the attractiveness of using bio-ethanol as an alternative fuel source, which would involve a range of other considerations.

\subsection{Conclusions}

The study's major finding is that ethanol helps to reduce U.S. gasoline prices today, and could potentially play an even larger role in the future by helping to reduce crude oil prices.

- Ethanol blending in the U.S. is keeping U.S. retail gasoline prices about 17 cents per gallon lower than they would be with no ethanol (14 cents if we subtract the cost of the ethanol subsidy ${ }^{7}$ ). As mentioned above, this takes into account the lower mileage impact of ethanol. If available ethanol volumes can be increased economically, ${ }^{8}$ ethanol has the potential to lower gasoline prices even further: with economic

6 In order to calculate the mileage adjustment for the different national average ethanol blending levels (E10, E15, E20), we did assume that there would be homogeneous blending up to those levels.

7 Subsidy per gallon of ethanol is 51 cents, and the average gallon of U.S. ethanol today contains 0.064 gallons of ethanol (6.4\% national ethanol concentrations).

8 For the purpose of this analysis, ethanol is considered "economic" when blending is done to achieve an economic benefit, not to fulfill a requirement. 
blending to an average ethanol concentration of 20 percent nationwide, the per-gallon savings (mileage adjusted) could reach 18 to 63 cents ( 7 to 52 cents if we subtract the cost of the ethanol subsidy). Note that these figures do not take into account the costs associated with the build-out of infrastructure needed for the higher ethanol blending concentrations.

- Ethanol has become the main source of additions to the world fuel supply outside of OPEC, and thus has the potential to moderate crude oil prices by reducing demand for crude oil. To date, however, the effect of ethanol blending on crude oil prices has been limited, as crude oil demand today is driven by strong demand for diesel, not gasoline, and ethanol acts as a gasoline substitute. If and when the diesel shortage is resolved, the lower gasoline demand brought about by ethanol blending will then result in reduced demand for crude oil. At that point, crude oil prices could fall, leading to substantially greater reductions for gasoline at the pump. Multiple other factors impact crude oil prices, and in particular, OPEC can react to decreasing crude oil prices by reducing production. Therefore, this study does not attempt to quantify this impact of ethanol on gasoline and broader fossil fuel prices.

The remainder of this document provides more detail on the short-term effect of ethanol blending on gasoline prices and its longer-term impact on crude oil prices. 


\section{Reducing Gasoline Prices at the Pump}

\subsection{Introduction}

The level of ethanol in the U.S. today, 6.4 percent of the national gasoline supply, has resulted in retail gasoline prices 17 cents per gallon (mileage-adjusted) lower than they would be without ethanol. That number translates to about $\$ 115$ in annual savings for the individual driver and approximately $\$ 24$ billion in annual savings for U.S. drivers as a whole. These benefits come at a cost of $\$ 4.6$ billon per year -3 cents per gallon of gasoline in ethanol subsidies. This amounts to an annual subsidy per U.S. driver of $\$ 22$, and an annual cost of $\$ 15$ for every U.S. citizen ${ }^{9}$.

Incremental economic ethanol blending in the gasoline supply could yield even greater savings (Exhibit 2). A 10-percent national average concentration could result in retail gasoline prices 19 to 50 cents per gallon (mileage-adjusted) lower than they would be with no ethanol, assuming a price environment that ranges from crude oil at $\$ 60$ per barrel and corn at $\$ 4$ per bushel (lower limit of savings), to crude oil at $\$ 120$ per barrel and corn at $\$ 3.50$ per bushel (upper limit of savings) ${ }^{10}$. The total annual subsidy would be $\$ 7$ billion at 10-percent. A 15-percent concentration could result in savings of 20 to 59 cents per gallon (mileage-adjusted), and a 20-percent concentration could result in savings of 18 to 63 cents per gallon (mileage-adjusted) compared to no blending, for the same assumptions for crude oil and corn prices. The annual subsidies would be $\$ 11$ billion at 15 -percent, and $\$ 15$ billion at 20 -percent.

There are five impacts from ethanol blending that result in reduced gasoline prices (Exhibit 2). The first two impacts - that ethanol is a cheaper blendstock than fossil gasoline at current corn and crude oil prices and that it is the best oxygenate - are associated with ethanol's relative cost-effectiveness. The next three pertain to ethanol's impact on the price of fossil gasoline: ethanol increases the fossil gasoline yield at the individual refinery level, it reduces expensive fossil gasoline imports in the U.S., and it contributes at the global level to the gasoline overcapacity (relative to diesel).

There are varying levels of certainty over the contribution from each impact. The first two impacts are associated with price movements. The substitution effect (cheaper blendstock) is the most uncertain as it is dependent upon the price movements of corn and crude oil. The second impact has a broad range due to the potential price movements of alternative oxygenates between current pricing and marginal production economics. The remaining impacts are less based on price movements, but instead on structural changes in demand or in production which provide a more certain impact. The first two impacts are responsible for the vast majority of the range in the total impact.

9 Population of U.S. is 302 million people and number of U.S. drivers is 205 million (2007).

10 While corn price will deviate from the $\$ 3.50$ to $\$ 4.00$ price range, the actual ratio between crude and corn price is likely to stay within the boundaries of the scenarios described. This ratio, rather than the absolute prices drives the savings. 


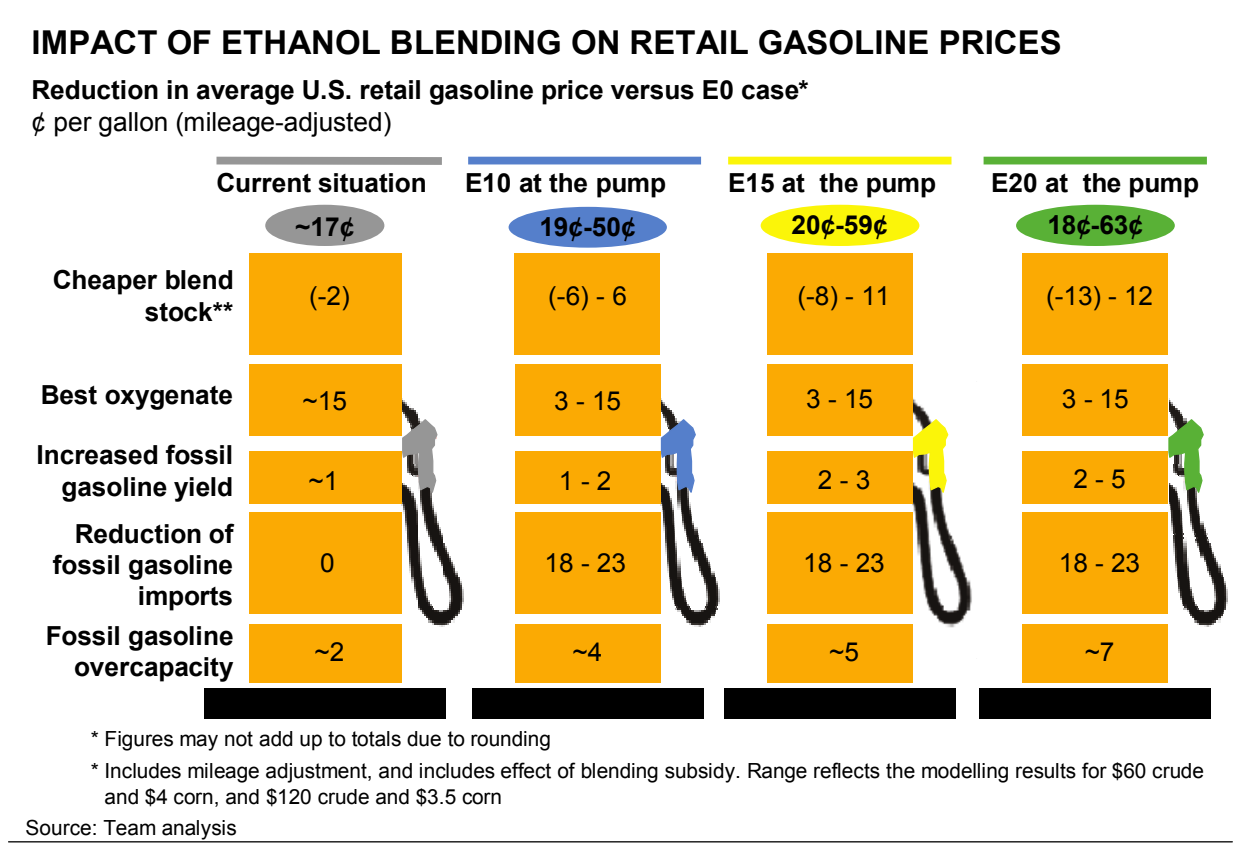

Figure 2. Impact of ethanol blending on retail gasoline prices

\subsection{Cheaper Blendstock at Current Corn and Oil Prices}

Whenever a gallon of ethanol is cheaper than a gallon of fossil gasoline, adding more ethanol as a blendstock will reduce the production cost of finished gasoline. Which component is less expensive depends on the price of corn (as the marginal source of ethanol in the US) and the price of crude oil, the feedstock for fossil gasoline. If all other variables are equal, higher corn prices make fossil gasoline more attractive; the reverse is also true - higher crude oil prices make ethanol relatively more economical. Exhibit 3 depicts this substitution effect conceptually based on the average prices during the first three quarters of 2008 .

However, even though ethanol was a cheaper feedstock than fossil gasoline during the first three quarters of 2008 , less than $70 \%$ of gasoline in the U.S. sold during that period contained ethanol, even though spare ethanol production capacity was available.

This is the result of logistic constraints in the ethanol supply chain that make it impossible for certain blenders to acquire ethanol, or make ethanol logistics prohibitively expensive compared to fossil gasoline. Gasoline blenders traditionally receive gasoline components by pipeline from the refineries, whereas the main cost-effective, long-distance solution today to transport ethanol from the production plants to the demand areas is rail ${ }^{11}$. Some blenders do not have access to rail or are too far removed from an ethanol terminal (where the ethanol can be transferred from railcar to truck) to make ethanol economically attractive for them.

11 Note that the pipeline infrastructure to transport ethanol is gradually being built out. 


\section{IMPACT OF ETHANOL BLENDING ON GASOLINE PRODUCTION COST}

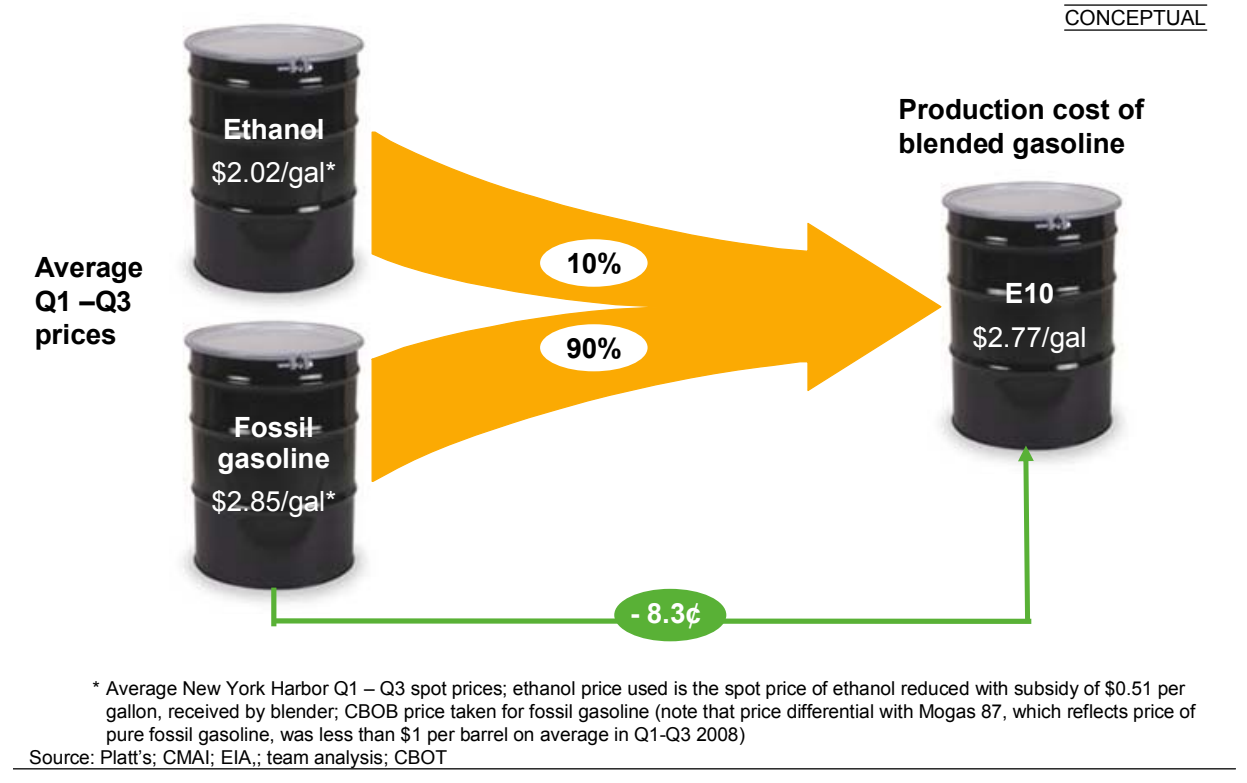

Figure 3. Impact of ethanol blending on gasoline production cost

Because of these logistical constraints, there are many areas in the U.S. today where there is not sufficient access to ethanol to allow all gasoline blenders to blend ethanol up to the economical level. The gasoline marketers selling E0 in these markets have to set their gasoline prices higher to cover their costs, and these prices in turn help set the overall retail gasoline price in the region. Blenders who produce E10 gasoline benefit from a higher profit margin on their volume of E10, due to their lower input costs when they compete against E0 suppliers. Exhibit 4 shows this conceptually.

For instance, in reformulated gasoline (RFG) markets, where ethanol is blended to meet legal requirements (see section 2.3), the ethanol import infrastructure is typically well developed, ethanol concentrations can be expected to be fairly uniform, and the lower production costs when ethanol is cheaper than fossil gasoline - will translate to lower gasoline prices at the pump. In other areas, where blenders need to rely for instance on ethanol imports by truck, ethanol concentrations will not be homogeneous, and the savings from lower gasoline production costs due to ethanol blending will typically not be passed through to consumers at the pump. 
SUFFICIENT ETHANOL MUST BE AVAILABLE TO THE BLENDERS IN THE MARKET FOR COST REDUCTION TO BE PASSED THROUGH TO DRIVERS

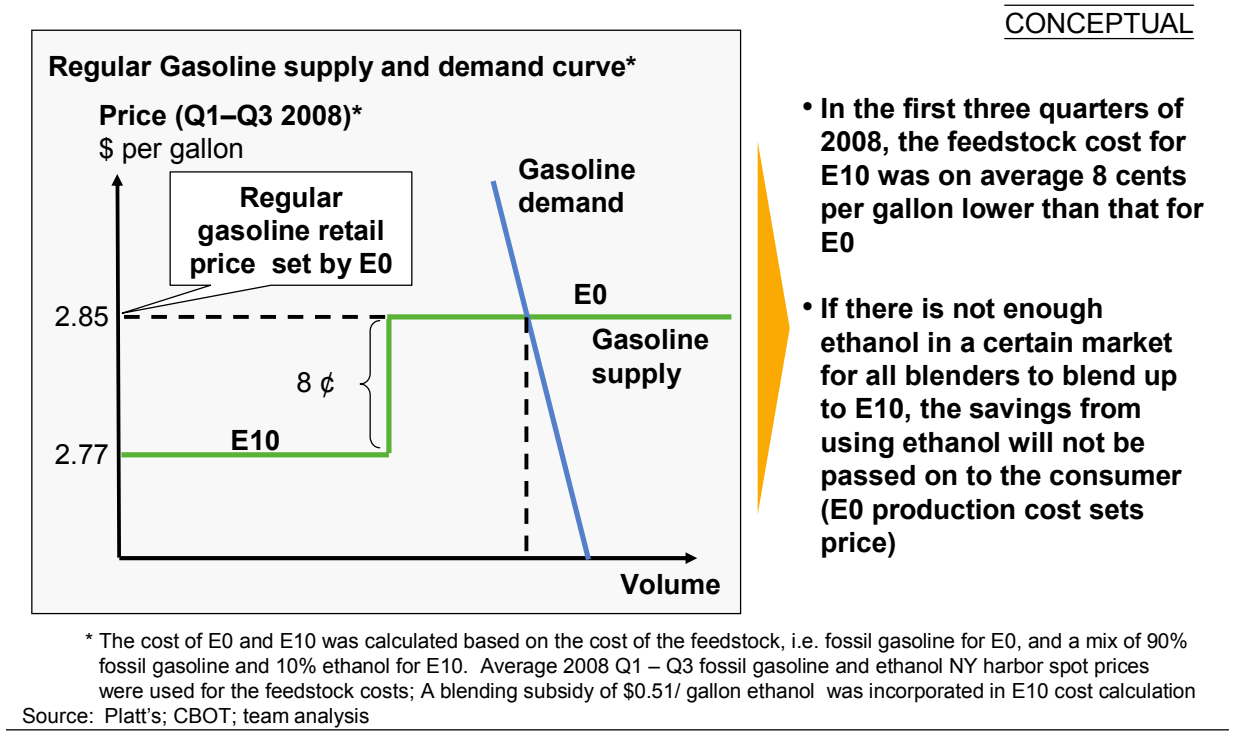

Figure 4. Sufficient ethanol must be available to the blenders in the market for cost reduction to be passed through to drivers

While ethanol can yield lower prices at the pump, even when the benefit is passed through, the end consumer may not be better off. Ethanol has a lower energy content than fossil fuel, resulting in a reduced mileage per gallon. Adjusting for the $3.88 \%$ loss in mileage per gallon for E10 implies a driver will need to purchase 1.04 gallons of E10 to drive the same distance as he would have driven with E0. When factoring in the additional volume required to be purchased, the net benefit to the end consumer can be substantially reduced and in some cases be negative. When ethanol is priced greater than $61.2 \%^{12}$ of the fossil gasoline price (the mileage equivalency point), the result will be a reduction in the price at the pump, but an increase in cost to the consumer due to the additional volume required to be purchased.

\subsubsection{Approach}

We used the following approach to quantify the impact of ethanol on gasoline production cost through this substitution effect. First, we assessed what the costs to the gasoline blender are of fossil gasoline and ethanol, both today and in the scenarios with increased national average ethanol concentrations. For the cost today, we used the actual wholesale prices ${ }^{13}$ of fossil gasoline destined for blending with ethanol (also called $\mathrm{CBOB}^{14}$ ) and ethanol adjusted as needed for transportation costs, ethanol subsidies, etc. - to calculate the

12 Oak Ridge National Laboratory's October 2008 report (Effects of Intermediate Ethanol Blends on Legacy Vehicles and Small Non-Road Engines) states that the mileage loss from E10 vs. E0 is 3.88\%, implying a mileage reduction for ethanol of $38.8 \%$. Ethanol priced above this discount will effectively cost more per mile for the consumer.

13 Average New York Harbor spot prices for CBOB and ethanol in the first three quarters of 2008 were used. 14 Conventional Blendstock for Oxygenate Blending 
production cost of blended gasoline. We compared this to the wholesale price of pure fossil gasoline (delivered to the blender) to determine the impact of ethanol on the gasoline production cost of a blender.

We used a modeling approach to determine the input costs to the blender in the scenarios with increased ethanol blending concentrations. We modeled the fossil gasoline price based on crude oil prices of $\$ 50$ to $\$ 150$ per barrel of oil, using McKinsey's Price Equilibrium model for a Fluid Catalytic Cracking (FCC) configuration, which is the primary marginal U.S. gasoline production configuration ${ }^{15}$. The model solves for the optimal prices for the configuration's products, given the specific output of the FCC configuration and the typical pricing relationships between the different products. The effect was modeled using an FCC configuration rather than the hydroskimming configuration of the refineries in Europe, Middle East and Asia that currently provide the marginal barrel of gasoline to the U.S. (and thus set the gasoline price in the U.S.), to make the impact of this effect additive to the impact that ethanol can have on gasoline prices through elimination of those imports (see further for "Reduction of fossil gasoline imports"). In order to determine the cost of ethanol to the blender, we assessed what the marginal source of ethanol would be, as the marginal source sets the price to the blender in efficient markets.

Exhibit 5 shows the 2008 marginal cost curve of ethanol, delivered to a gasoline blender in the U.S. ${ }^{16}$ As can be seen from the graph, U.S.-produced corn-based ethanol is the marginal source of ethanol in the U.S. The ethanol supply capacity in the U.S. today, excluding Brazilian imports not exempted from the 54 cents U.S. import tariff, is about 10 billion gallons per year, thus providing spare capacity above the 9 billion gallons required by the Renewable Fuel Standard (national average ethanol concentration of 6.4\%).

\section{Methodology: Prices set by marginal costs}

In order to model prices for the different commodities under the different scenarios, we developed marginal cost curves (supply curves) using a bottom-up cost calculation. Price points for the commodities in the different scenarios (E10, E15 and E20) are set where demand meets supply. In order to model the different impacts of ethanol on gasoline, we developed the following supply curves as part of this effort:

- Regular gasoline (substitution effect, exhibit 4)

- Ethanol delivered to the blender (substitution effect, exhibit 6)

- Fossil gasoline (substitution effect and gasoline import effect, exhibit 11)

- Oxygenates (oxygenate effect)

15 FCC rather than Hydro-skimming capacity was considered as marginal source in U.S. as the hydroskimming capacity is so small. A long-run diesel to gasoline spread of \$1 per barrel, based on 1996 to 2005 average spread, was used for the modeling.

16 The price of ethanol delivered to blender was modeled based on corn price of \$5.6. Price of Brazilian ethanol modeled based on sugarcane price of $\$ 143 /$ ton. 
TODAY'S U.S. ETHANOL SUPPLY CURVE

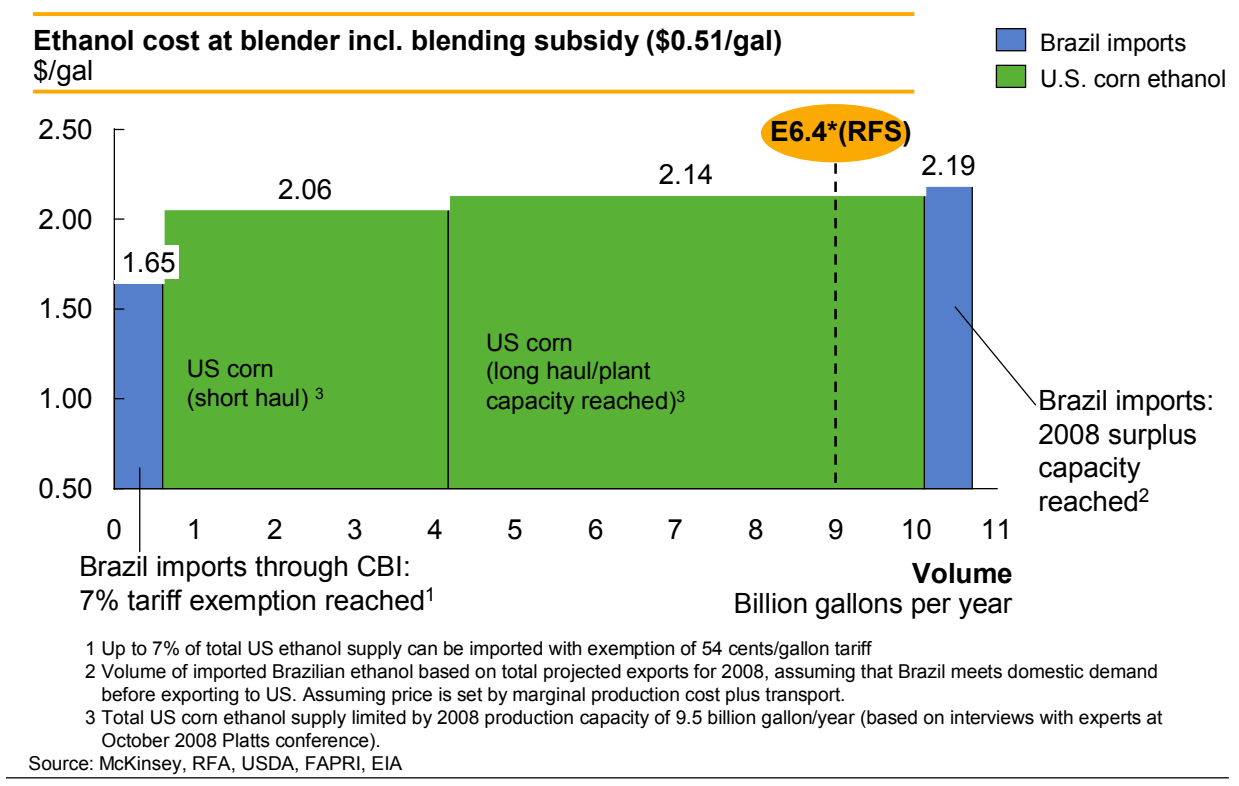

Figure 5. Today's U.S. ethanol supply curve

However, in order to reach national average ethanol concentrations of $10 \%$ or more, a combination of increased supply of corn-based ethanol and Brazilian sugarcane-based ethanol, as well as cellulosic ethanol, will be required. Based on today's subsidies and tariffs, we found that U.S. corn-based ethanol would remain the marginal source of ethanol in most of the likely scenarios ${ }^{17}$, thus setting the price of ethanol to the blender. Therefore, we modeled the cost of ethanol to the blender using the cost structure of corn-based ethanol, for corn prices of $\$ 2.00-7.00$ per bushel.

This analysis assumes that ethanol volumes can be increased economically over time to meet the higher national average ethanol concentrations in the different scenarios (10 percent, 15 percent and 20 percent). However, situations may arise where ethanol prices could be well above the levels we have assumed in this analysis, e.g. because cellulosic ethanol struggles to come on line or remains prohibitively expensive despite the subsidy of $\$ 1.01$ per gallon, or because a shortfall of ethanol supply versus the mandated volumes arises at a certain point that leads Europe and the U.S. to bid up the price of imported Brazilian ethanol ${ }^{18}$.

We used the following approach to determine the extent to which the lower production cost of blended gasoline was passed through during the first three quarters of 2008. First, we

17 The key assumption is that U.S. cellulosic ethanol will become commercially available over time at a cost below corn-based ethanol, but not in sufficient volumes to fully displace corn-based ethanol supply.

18 In the event of an actual shortfall versus RFS mandates, the price of the RINs (Renewable Identification Numbers) that are obtained by blending ethanol and that refiners need to show as proof that they have blended ethanol in line with their overall gasoline production, can rise dramatically and lead to significant increases in gasoline prices at the pump. 
assumed that in states that contain RFG markets (Exhibit 6), the reduction in gasoline production cost would be passed through fully to the drivers. The underlying assumption is that the RFG regulation results in well-developed ethanol logistics infrastructure that the non-RFG markets in the state can benefit from.

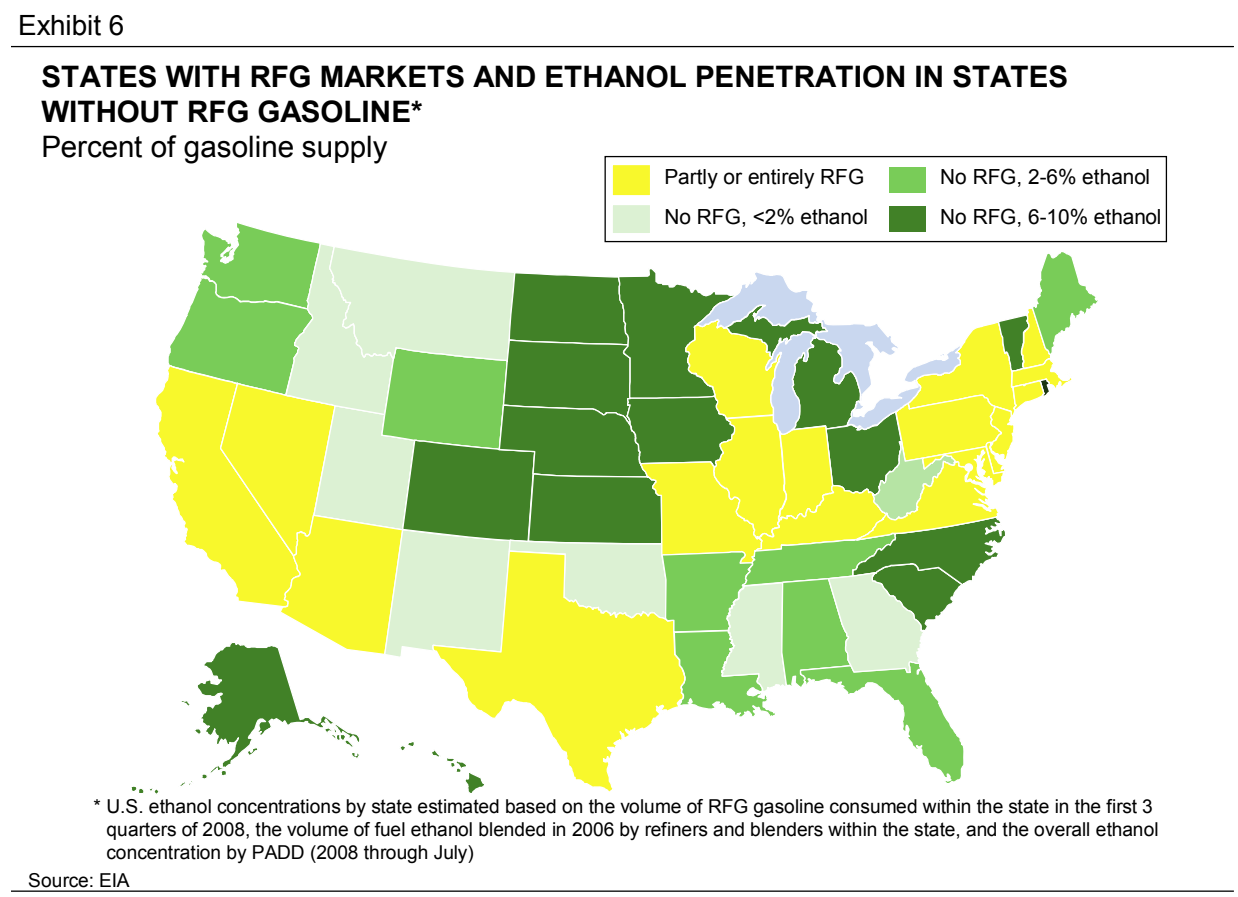

Figure 6. States with RFG markets and ethanol penetration in states without gasoline

For the states without any RFG markets, we first determined the ethanol concentration based on the total amount of ethanol blended by refiners and blenders within the state. We took into account any state and federal limits on the ethanol concentration to determine which portion of ethanol blended within the state is exported and consumed outside of the state, and we took into account imports from other states. Exhibit 6 shows the ethanol concentrations in these non-RFG states. We then calculated, by state, what the savings would be from ethanol if they were passed through fully to consumers. Finally, we applied a discount factor to these savings, based on the average ethanol blending level in the state, to account for reduced passthrough in markets without homogeneous blending. For states with an average ethanol blend level below 2 percent, we assumed that none of the savings were passed through to consumers. For states with average ethanol blend levels between 2 percent and 6 percent, we assumed that 50 percent of the savings were passed through. Finally, for states with ethanol blend levels above 6 percent, we assumed all savings were passed through.

For the scenarios with $10 \%, 15 \%$ and $20 \%$ national average ethanol concentrations, we assumed that the change in production cost due to ethanol blending would be fully passed through to the consumer. Indeed, as the available volume of ethanol increases and the market reduces bottlenecks in the ethanol supply chain, more gasoline marketers will be able to 
blend up to the legal maximum in their market, and the price at the pump will more fully reflect the reduced input component costs.

Finally, we adjusted the impact of the substitution effect to account for the lower fuel economy of the blended gasoline (E6.4, E10, E15 and E20) compared to E0.

\subsubsection{Findings}

Based on actual average gasoline and ethanol prices during the first three quarters of 2008 , we found that a gallon of ethanol was, on average, 83 cents cheaper than a gallon of fossil gasoline. Thus, the average production cost of E10 during this period was 8.3 cents per gallon lower than that of E0 (see Exhibit 3). For a hypothetical gallon of E6.4, the average gallon of U.S. gasoline, the production cost was 5.3 cents lower than for E0 (without adjusting for reduced mileage of E6.4).

Following the approach described above, we determined to what extent these lower production costs would result in lower gasoline prices at the pump in the different states. We found that during the first three quarters of 2008, about 15 million gallons of ethanol were blended per day in the 20 states that have RFG markets. Given that every gallon of ethanol resulted in a saving of 83 cents for the blender, this amounts to a savings of $\$ 12.5$ million per day in these states with RFG markets, all of which are assumed to be passed through to consumers. About 9 million gallons of ethanol were blended per day in states without any RFG markets. This leads to a reduction in gasoline production cost of $\$ 7.5$ million per day in these states. However, following the approach lined out in Section 2.2.1, we found that only $\$ 6.2$ million per day was passed through to consumers. Thus, while the 24 million gallons of ethanol blended in the U.S. per day result in reduced gasoline production costs of $\$ 20$ million per day, only $\$ 18.7$ million, or 93.5 percent, is passed through to the consumers. Thus, on average, every gallon of ethanol blended reduces the gasoline production cost by 83 cents, but the price to consumers by only 78 cents. For the current market, where the production cost of E.6.4 is 5.3 cents per gallon lower than for E0 (see above), only $93.5 \%$ or 4.9 cents are passed through to consumers.

Furthermore, as the E10 blend has a lower mileage than the original E0, the consumer will need to purchase additional volume to achieve the same mileage. The consumer will need to purchase approximately 1.04 gallons, resulting in an additional charge of 7.0 cents. This additional cost offsets the benefit of the cost reduction above. The reason for this effect is that while ethanol is priced less than fossil gasoline, it is priced higher than its mileage equivalency, resulting in an increased cost per mile. The net impact of the substitution effect in the first three quarters of 2008 was an increase of the average price of a mileage-adjusted gallon of gasoline of about 2 cents.

We estimated the impact of the substitution effect at higher national average ethanol blend levels by looking at two scenarios with different feedstock price assumptions. For the lower limit of the estimate, we used a scenario with crude oil at $\$ 60$ per barrel and corn at $\$ 4$ per bushel, while we used a crude oil at $\$ 120$ per barrel and corn at $\$ 3.5$ per bushel to determine the upper limit of the estimate. The scenarios were chosen as they represent two relatively extreme pricing environments. In the lower limit scenario the ratio of crude oil to corn price 
is $15: 1$, while in the upper limit scenario, the ratio is $34: 1$. Since 2005 , the actual ratio (based on average monthly prices) has only once been below 15:1, and never above 34:1. Exhibit 7 shows the impact of the substitution effect (assuming full pass-through of the reduced production cost to consumers, and after mileage adjustment) for E10.

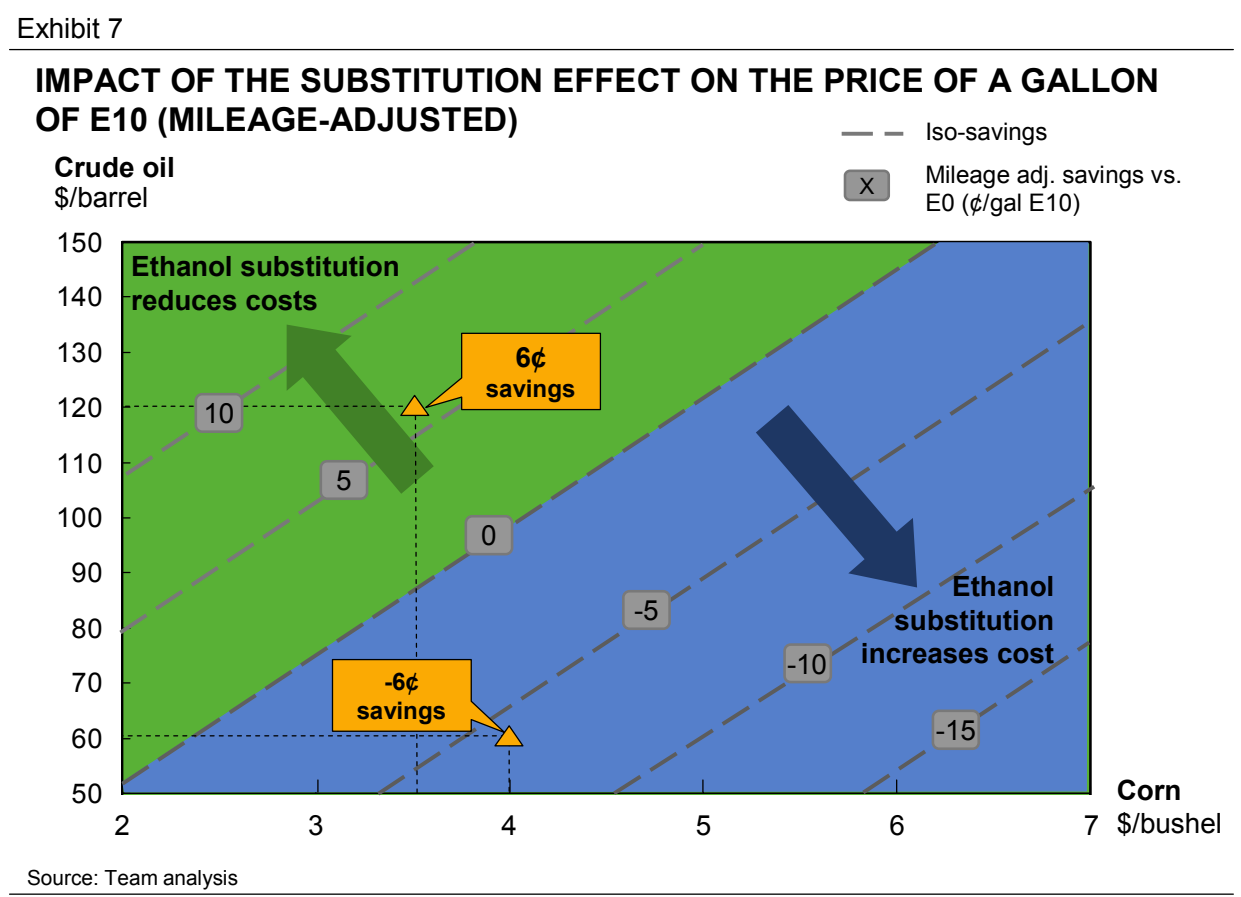

Figure 7. Impact of the substitution effect on the price of a gallon of E10 (mileage-adjusted)

As can be seen from the graph, the price of a gallon of E10 (mileage adjusted) is between 6 cents higher and 6 cents lower than that of E0, depending upon the relative price of crude oil and corn.

The price of a gallon of E15 is between 8 cents higher and 11 cents lower $^{19}$, and the price of a gallon of E20 is between 13 cents higher and 12 cents lower than that of E0. As mentioned above, for the 10 percent and higher national average ethanol blending levels, we assumed that the gasoline production cost savings from ethanol will be fully passed through to the drivers.

\subsection{Best Oxygenate in Reformulated Gasoline Markets}

Approximately $30 \%$ of U.S. gasoline is reformulated gasoline (RFG), which is required in areas where high population density has led to more stringent clean air regulations. These markets effectively require gasoline to include an oxygenate that adds $2.1 \%$ of oxygen to the

19 For E15, the substitution effect is more skewed towards decreasing the cost of gasoline, compared to E10 and E20. This reflects the relative better mileage of ethanol when it is blended in E15 gasoline as compared to $\mathrm{E} 10$ and E20. 
gasoline $^{20}$, to make it burn more cleanly, hence the name reformulated gasoline. Historically $\mathrm{MTBE}^{21}$ was the oxygenate of choice, but it was phased out in 2006 due to concerns about its carcinogenic properties. At the time of the MTBE phase out, the EPA and states such as California, examined potential oxygenate substitutes. Ethanol emerged as the best alternative, and today, virtually all gasoline in RFG markets contains ethanol to meet the oxygenate requirements.

\subsubsection{Approach}

To estimate the value of ethanol as an oxygenate in RFG markets, we looked at the cost of the best (most cost-effective and acceptable from an environmental and health perspective) available alternative in the short and in the long term. To identify the best available options, we first categorized the potential oxygenate substitutes into viable and non-viable alternatives. Certain substances - methanol, MTBE and TAME were eliminated based on environmental and health risks, and DME was eliminated because it has not been tested as a gasoline additive. ${ }^{22}$ Isopropanol, ETBE, butanol and bio-butanol, listed in order of cost to produce, were considered viable substitutes.

Having identified the potential substitutes, we assessed the quantities available of each potential substitute today. Today, none of the viable substitutes are produced at sufficient volumes to replace on their own the roughly 2.7 billon gallons of ethanol used as an oxygenate. As a result, blenders would have to use various substitutes to meet the requirement. Therefore, we developed a marginal cost curve for meeting the $2.1 \%$ oxygenate requirement in RFG markets in the absence of ethanol in the short run, based on average spot prices of the different substitutes during the first three quarters of 2008. Fossil butanol, one of the most expensive alternatives, would likely be the marginal source of oxygenate in the short run if there was no ethanol, even if we assume that the entire global production of all the viable alternatives is made available to replace ethanol in U.S. reformulated gasoline.

If ethanol were truly not available, eventually chemical producers would scale up production of cheaper alternatives. Based on a comparison of marginal production costs of the different alternatives, isopropanol would likely be the most cost-effective long term substitute in the U.S. market. The production cost for isopropanol was calculated using the modeled feedstock costs (natural gas and propylene) using $\$ 60$ per barrel of crude oil ${ }^{23}$.

\subsubsection{Findings}

Blending ethanol as an oxygenate is keeping gasoline prices in RFG markets today about 51 cents per gallon lower than they would be with no ethanol. This figure reflects the short-term cost of switching to butanol as the marginal source. Overall, with RFG markets accounting

20 This is no longer a legal requirement, as the law just stipulates the emission characteristics. However, in practice, an oxygen-containing component needs to be added to meet those emission characteristics in a costeffective way.

21 Methyl-tertiary-butyl ether.

22 MTBE (carcinogenic), TAME (listed by the EPA as a potential hazard); methanol (no longer in widespread use in the U.S., primarily due to safety issues).

23 We used a price of $\$ 60$ per barrel of crude oil, rather than the EIA's long-term forecast of \$69 (AEO 2008), as we are determining the lower end of the range of savings. 
for $30 \%$ of U.S. gasoline consumption, this amounts to a reduction of the average U.S. gasoline price today of about 15 cents per gallon.

For the 10 percent, 15 percent and 20 percent national average blending level scenarios, we developed a range for the impact of ethanol as an oxygenate. The high end of the range reflects the short-term cost of switching to butanol (15 cents per gallon). The low end of the range was determined by assessing how much more expensive the gasoline production cost would be if the $2.1 \%$ oxygen requirement would be met with isopropanol (at $\$ 60$ per barrel of oil) rather than with ethanol (at \$4 per bushel of corn). Taking into account their production cost per gallon as well as their oxygen content (35\% for ethanol and $27 \%$ for isopropanol), we calculated savings of 3 cents per gallon of gasoline for the low end of the range. Note that the savings of 3 to 15 cents per gallon of gasoline apply to the 10 percent, 15 percent and 20 percent national average blending level scenarios, as the oxygenate requirement is already fulfilled at about $2 \%$ national ethanol concentration and the savings thus do not scale up as the ethanol concentration is increased.

As an additional point of context, when ethanol replaced MTBE as the oxygenate in gasoline in 2006, shortages of ethanol at the time drove blenders to use alternatives. In the period of April to July 2006, when ethanol was most scarce, reformulated gasoline prices spiked to approximately 40 cents per gallon higher than would be expected based on the crude oil prices at the time. ${ }^{24}$ This is an additional indication how much more expensive gasoline could be in the short run without ethanol.

\subsection{Increased Fossil Gasoline Yield per Barrel of Oil}

Regular gasoline sold in the United States requires an octane number ${ }^{25}$ of at least 87 . Crude oil refining produces multiple different outputs, and fossil gasoline is a blend of many of these outputs, for instance FCC gasoline (the gasoline stream coming out of the FCC unit), naphtha and butane. High-octane isomerate and reformate, produced by converting lowoctane naphtha streams in an isomerization unit and a reformer, respectively, are typically added to meet the octane requirement.

With an octane number of 113 , ethanol is an excellent source of octane for a target 87 octane gasoline blend. As a result, refiners producing fossil gasoline for blending with ethanol (called CBOB or Conventional Blendstock for Oxygenate Blending) can increase the percentage of low-octane naphtha in the gasoline blend and reduce the isomerization unit and reformer throughput. Since the conversion of naphtha to isomerate and reformate results in gasoline volume loss (hydrogen and other low value light end components are produced as by-products), less processing results in higher yields of fossil gasoline per barrel of crude oil. Exhibit 8 gives a schematic overview of the fossil gasoline production process, and how

$24 \mathrm{We}$ assessed this effect by using the McKinsey Price Equilibrium model to determine the retail reformulated gasoline price, based on the assumption that U.S. wholesale gasoline prices would be set by the cost of importing gasoline produced in Northwest Europe on a hydro-skimming marginal configuration.

25 Anti-Knock Index (AKI) or Pump Octane Number (PON), which is equal to the average of the Research Octane Number and the Motor Octane Number. The octane in the gasoline increases the activation energy needed for auto-ignition of the gasoline. The higher activation energy means less knocking of the engine. 
ethanol blending allows the change the mix of the different fossil gasoline components in the final gasoline blend (decrease in isomerate and reformate and increase in naphtha).

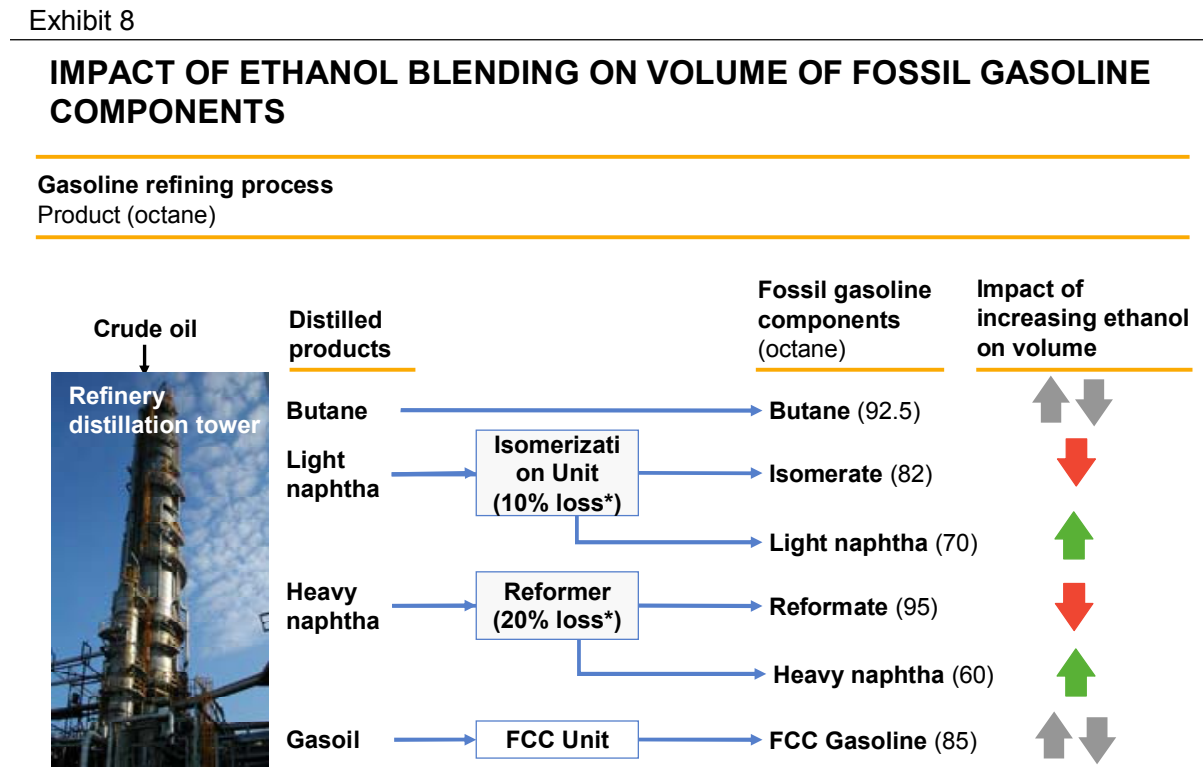

* Loss of fossil gasoline component volume. Other, lower-value products are produced in isomerization unit and reformer Source: Petroleum Industry benchmarks; McKinsey analysis

Figure 8. Impact of ethanol blending on volume of fossil gasoline components

The higher fossil gasoline yield comes at the expense of reduced yields of lower value products. As a result, refiners are now able to produce a more valuable mix of products out of the same barrel of crude oil. This will put downward pressure on the prices of all refined products. Due to competitive pricing, the marginal, price-setting refinery is just earning its costs of production, and a shift towards a more valuable product mix in this marginal refinery will therefore be offset by a reduction in prices of refined products, keeping the profits of the marginal refinery at zero. Note that this effect is not only lowers fossil gasoline prices, but prices of all products, including diesel, jet fuel and fuel oil.

\subsubsection{Approach}

We used a two-step approach to estimate the impact of this effect. First, using a Linear Programming (LP) model representing the marginal U.S. refining capacity (FCC configuration $)^{26}$ and average product prices during the first three quarters of 2008 , we solved for the most valuable mix of products, for 0 percent, 10 percent, 15 percent and 20 percent levels of ethanol blending. The model also calculated the input costs for each scenario to

26 In principle, as the marginal source of gasoline in the U.S. today are discretionary imports, we would ideally model the impact of the yield effect based on a hydro-skimming configuration in Europe, Middle East or Asia, whichever is the marginal source of gasoline for the U.S. However, note that modeling this impact for instance for a European Hydro-skimming unit would yield a similar result. 
account for changes in inputs (e.g., as the reformer and isomerization unit throughputs are reduced, additional hydrogen will have to be purchased).

Additional constraints were built into the model to ensure that at a macro-level, all product demand would continue to be met. As a result, lower yields only happened for products for which there are good alternatives, so reduced volumes would not drive up prices. We also verified that increases in the inputs required, specifically hydrogen, could be met without driving up the prices of the inputs. Using this approach, the optimal composition and yield of the fossil gasoline streams for each scenario (no blending, blending with 10 percent, 15 percent and 20 percent ethanol) was determined, as well as the yields of the other streams and the operating expenses.

Subsequently, we calculated the prices of the fossil gasoline streams (as well as all other streams) for the different scenarios. For this, we used the outputs of the Refinery LP model (volume and composition of the different product streams, as well as operating expenses) as inputs into McKinsey's Price Equilibrium model (see also Section 2.2.1).

\subsubsection{Findings}

Exhibit 9 shows the composition of the products produced by the FCC configuration, as well as the composition of the $\mathrm{CBOB}$. As the percentage ethanol with which the $\mathrm{CBOB}$ will be blended increases, the share of naphtha in the $\mathrm{CBOB}$ increases, while the share of isomerate and reformate decreases.

\section{Methodology: Accuracy of the modeling}

A number of proprietary McKinsey models were used for this analysis, including the LP Refinery and the Price Equilibrium model. These models are regularly updated and have been validated numerous times against real life situations.

During our effort, we validated the Price Equilibrium model by comparing the average NY Harbor spot price for Conventional gasoline during the first three quarters of 2008 (\$2.81 per gallon) with the price modeled with the Price Equilibrium model (using the average crude oil price during the period). We modeled the gasoline production cost of a European hydroskimming configuration and added the cost of transportation to come up with the NY harbor wholesale price of $\$ 2.92$ per gallon. The small delta can be partially explained by the fact that during certain periods in the first three quarters of 2008, no imports were taking place from Europe and prices were set by lower cost marginal sources.

Note that because the impact of a specific effect is always calculated by comparing two different model runs, any error on the margin in the model will only have a minimal impact on the final result. 


\section{OUTPUT OF THE REFINERY LINEAR PROGRAMMING MODEL}

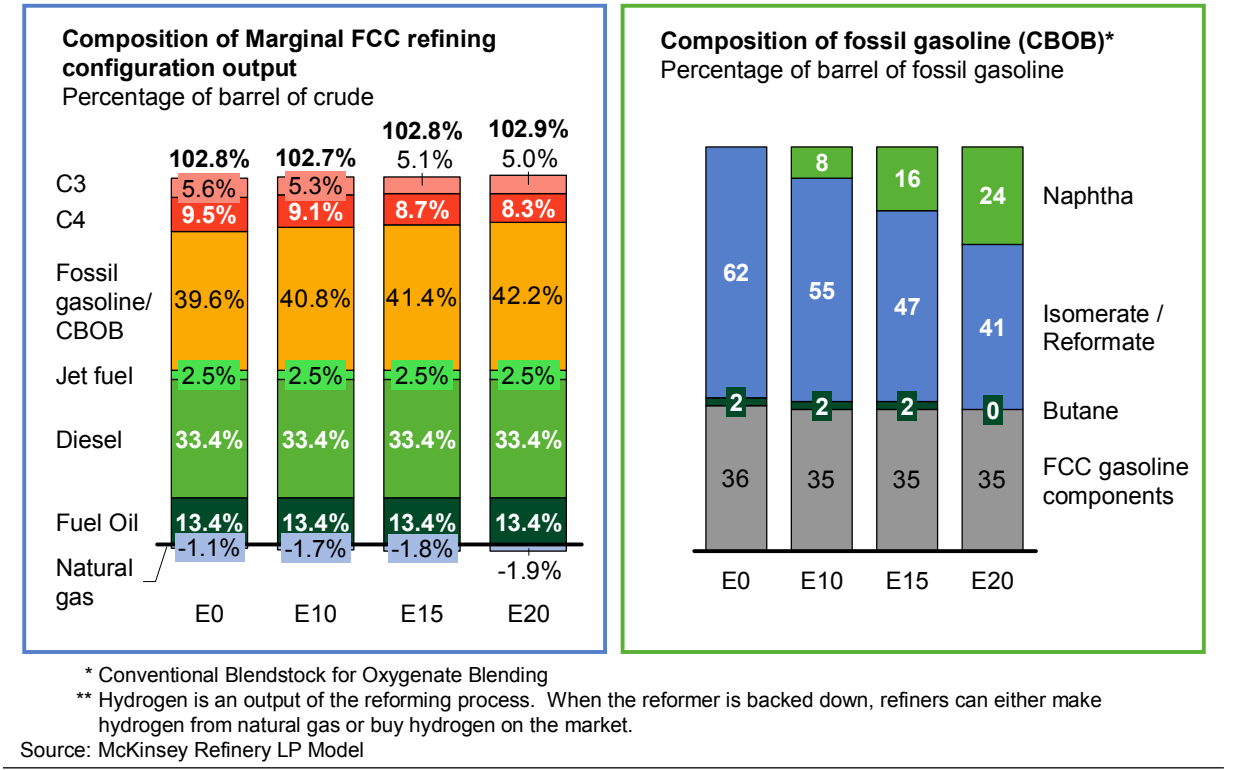

Figure 9. Output of the Refinery Linear Programming Model

Overall, we found that refiners producing fossil gasoline for E10 blending can produce approximately 3.2 percent more fossil gasoline from a barrel of oil than when they produce E0 (gasoline yield per barrel of crude increases from 39.6\% to 40.8\%), without additional investments in refining capacity. For E15 and E20, the fossil gasoline yield goes up by 4.7 and 6.7 percent, respectively. Using the outputs from the Refinery LP model in the Price Equilibrium model, we found that gasoline prices at the pump could fall 1 to 2 cents per gallon for E10 versus E0. For E15 and E20, the savings would increase to 2 to 3 cents and 2 to 5 cents, respectively. The impact today is calculated to be 1-2 cents based on extrapolation from the E10 savings. Note that our assessment assumes that the marginal, price-setting refinery is producing fossil gasoline for blending with ethanol. Furthermore, it assumes that refineries are effectively increasing their fossil gasoline yield at the expense of other components, which may not yet be fully the case today. ${ }^{27}$

27 Today, this effect may not be fully captured by all U.S. refineries producing fossil gasoline for blending with ethanol, but they should be able to capture this benefit over time. The increased gasoline yield is the result of reduced throughput in the reformer. A secondary effect of backing down the reformer is reduced production of hydrogen, which is required for desulfurization of diesel. For most refineries, this will not be a problem, as they typically have access to hydrogen produced from natural gas. However, some refineries in central Europe and Asia rely on internally produced hydrogen and would not be able to reduce throughput in the reformer to the same extent. 


\subsection{Reduced Fossil Gasoline Imports}

When the supply of fossil gasoline from U.S. refineries and structural, regional imports ${ }^{28}$ is insufficient to meet domestic demand, the United States fills the gap by purchasing refined fossil gasoline on the global market. These discretionary imports tend to be more expensive, because they come from marginal refining capacity in distant markets, typically Europe, Asia and the Middle East. These refiners sell their cargoes to the United States only if the U.S. gasoline wholesale price is high enough to cover their production and transportation costs, plus a margin for the risk of putting the gasoline in transit for several weeks. As a result, most of the time, the price of these marginal supply cargoes effectively sets the fossil gasoline price in the U.S. market, even though these imports make up only a small portion of the supply in the United States - in well functioning markets, the marginal source sets the price.

Note that even though these discretionary imports occur primarily in PADD 1 (Atlantic Coast), they set prices across the U.S. Indeed, PADD 3 (Gulf Coast) is the marginal domestic supplier of all regions (supplies PADD 1 and PADD 2 by pipe, and PADD5 by ship through the Panama canal). Consequently, when prices are set at import price parity in PADD 1, that price link ripples through to the other regions through PADD 3.

\subsubsection{Approach}

The addition of ethanol into the U.S. gasoline supply reduces the demand for fossil gasoline. We estimated the source of this displaced fossil gasoline by building a marginal cost curve for U.S. fossil gasoline. The wholesale fossil gasoline prices on the curve were modeled for different crude oil prices, using McKinsey's Price Equilibrium model for each of the refining configurations.

Fossil gasoline demand was determined for a scenario without any ethanol, with today's level of ethanol (6.4\%), and at higher national average ethanol concentrations $(10 \%, 15 \%$ and $20 \%$ ). For these volume calculations, we determined how many gallons of fossil gasoline a gallon of ethanol would displace, adjusted for the mileage loss associated with the different ethanol concentrations. Exhibit 11 shows the fossil gasoline supply curve for the U.S. in spring and summer season ${ }^{29}$, with fossil gasoline costs calculated based on a $\$ 111$ per barrel crude oil price (average price during first three quarters of 2008).

28 Mostly from Canada, the Caribbean and Northwest Europe.

29 The spring and summer seasons typically have the highest demand for gasoline in the United States. Winter and Fall, with lower required discretionary imports, will show the benefits of ethanol at lower national average ethanol concentrations (approximately 7\%). 


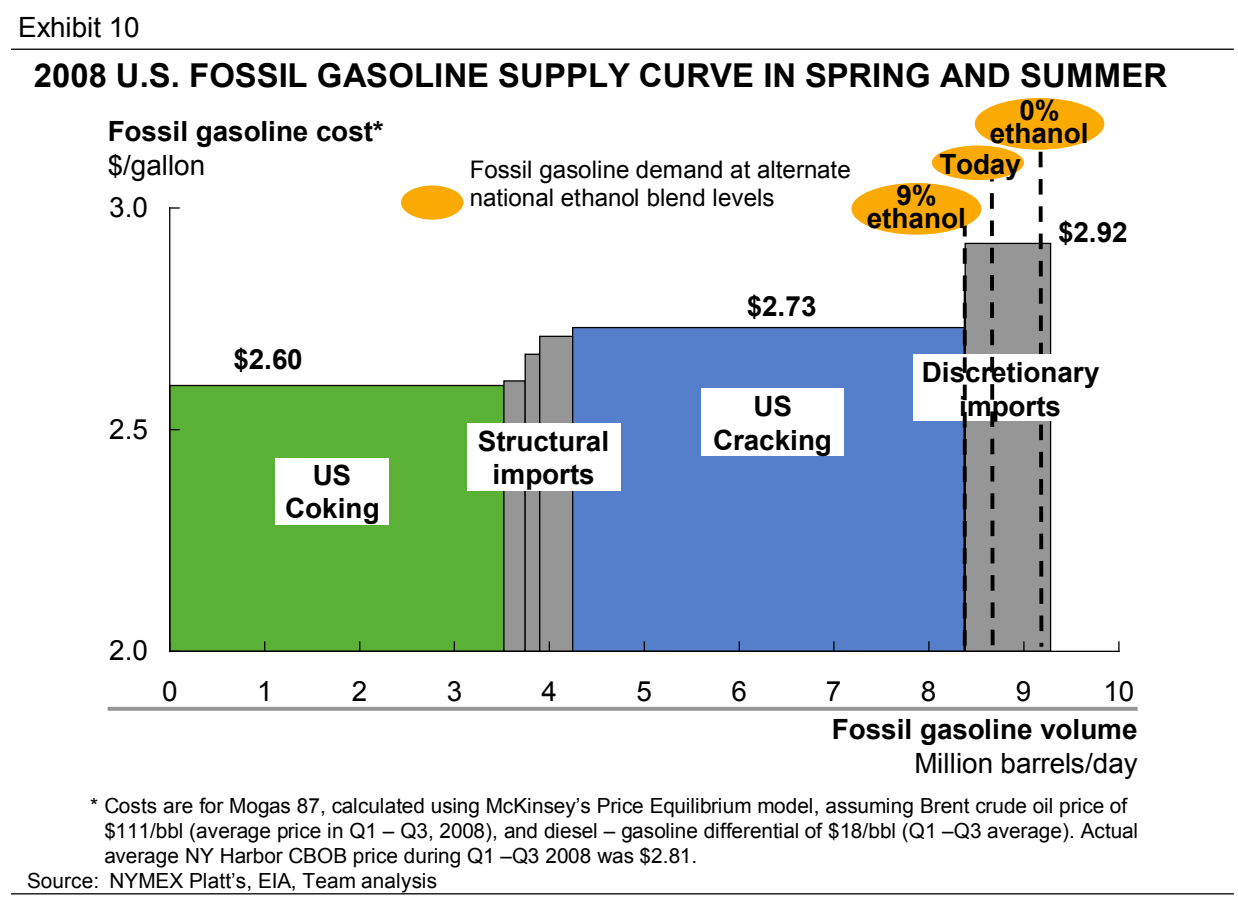

Figure 10. 2008 U.S. fossil gasoline supply curve in spring and summer

Using the marginal cost curves we were able to determine how the price of fossil gasoline would change as the demand shift created by ethanol moved the U.S. from a price set by discretionary imports to one set by domestic production. We were also able to calculate the associated volume of imported gasoline displaced by ethanol.

\subsubsection{Findings}

Ethanol has already helped reduce the United States' dependence on discretionary foreign imports. From 2005 to 2007, ethanol blending allowed the nation to eliminate 280 million barrels of high-cost, imported gasoline, reducing U.S. spending on foreign gasoline imports by $\$ 22$ billion over this period.

At present, the United States imports discretionary cargoes throughout the year. However, an average national economic ethanol concentration of 7 percent, just 0.6 percent above today's level, could eliminate discretionary imports during the fall and winter, when demand for gasoline is lowest. Achieving national economic ethanol concentrations above 9 percent would eliminate the need for these imports throughout the year (Exhibit 10). ${ }^{30}$

30 Given the lack of alternative markets for their excess gasoline, European refiners may actually have no other alternative than to continue exporting some of the discretionary volumes to the U.S. markets, by dropping the prices for their gasoline cargoes below the marginal cost of U.S. gasoline production. At that point, these previously discretionary imports would become structural imports, and the lower cost volume added through these additional structural imports would replace some of the marginal U.S. production capacity. Overall, the price savings would be at least as high as the savings figures mentioned above. 
At that point, gasoline prices would reflect the marginal cost of producing gasoline at U.S. refineries, a reduction of 18 to 23 cents, depending on the price of crude oil. Due to competition, drivers at the pump should see these benefits right away. ${ }^{31}$ If the United States economically meets the ethanol volumes specified in the Renewable Fuel Standard (RFS), ${ }^{32}$ it could achieve a national average of E9 gasoline and eliminate discretionary imports by $2010^{33}$ (Exhibit 11).

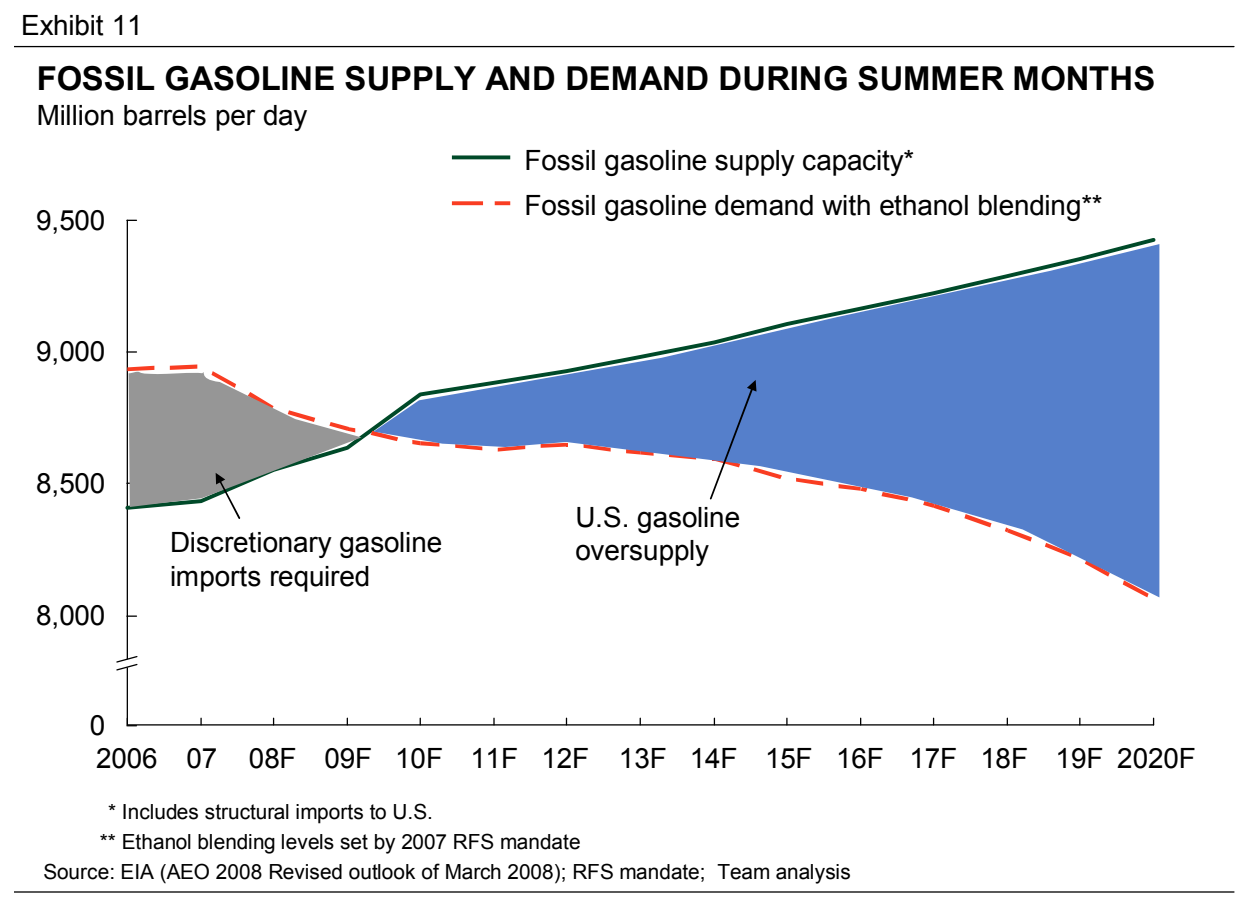

Figure 11. Fossil gasoline supply and demand during summer months

\subsection{Relative Fossil Gasoline Overcapacity}

Historically, gasoline and diesel prices per barrel have both traded at a similar premium to crude oil, with about a $\$ 1$ differential between gasoline and diesel. However, in recent years, the differential between diesel and crude oil has increased dramatically, while the differential between fossil gasoline and crude oil has fallen, and was even briefly negative for a period in the first half of 2008. This has caused the spread between diesel and gasoline prices to increase significantly - to an average spread of $\$ 18$ in the first three quarters of 2008 (Exhibit 12).

31 U.S. refiners could see substantial margin erosion as a result of eliminating foreign discretionary imports. They would be earning 18-23 cents less of margin per gallon on all of their production.

32 The Renewable Fuel Standard of 2007 specifies the volume of ethanol to be blended into gasoline in the U.S. each year through 2022. For 2022, the quota is a minimum of 31 billion gallons.

33 Without any ethanol, this would most likely not happen before 2020, based on planned refining capacity expansions. 
Exhibit 12

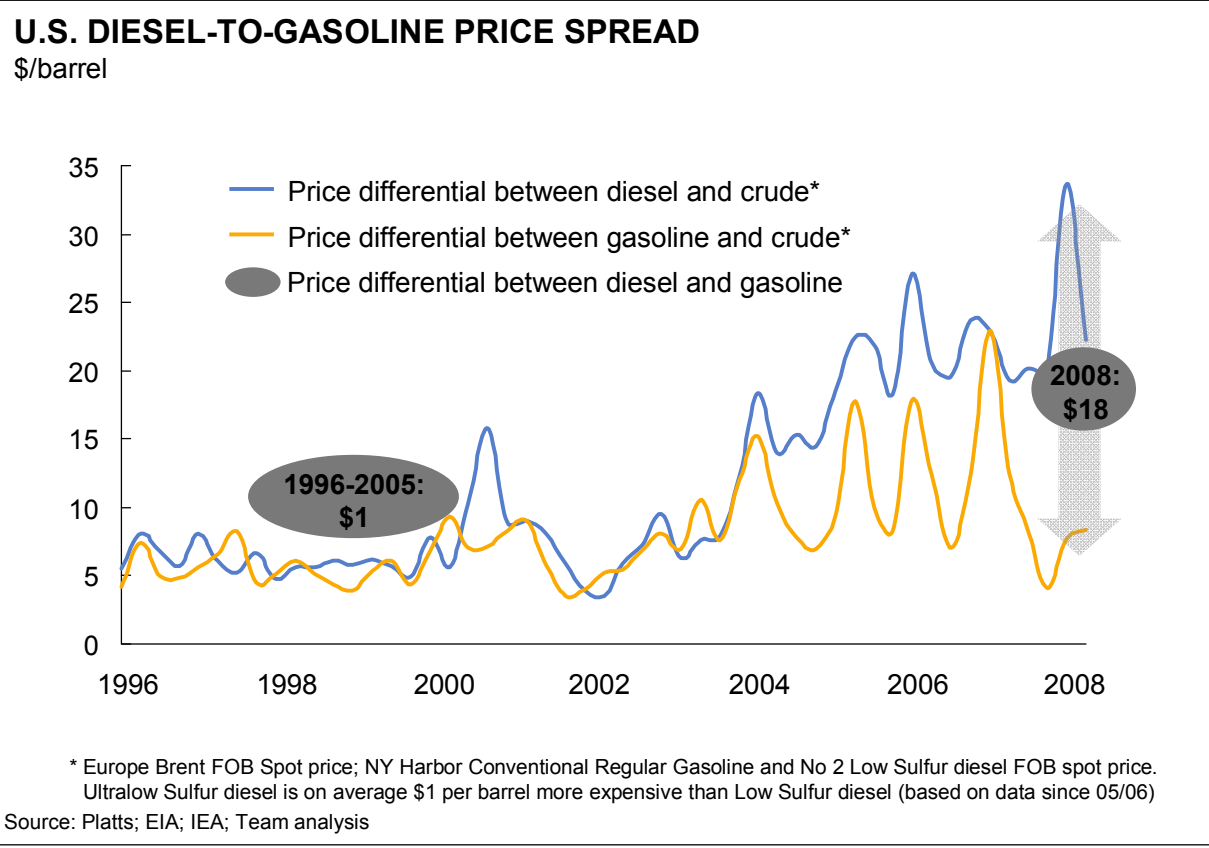

Figure 12. U.S. diesel-to-gasoline price spread

The two main drivers of this effect have been an increase in diesel demand - primarily from rapidly growing economies in China, India and the Middle East - and the offset to gasoline demand growth from increasing volumes of ethanol blended into the global gasoline supply. These effects are compounded by the fact that there is only limited flexibility to selectively increase the production of diesel without producing gasoline: diesel and fossil gasoline are produced simultaneously in the refining process, ${ }^{34}$ with the marginal refinery producing roughly two barrels of gasoline components for each barrel of diesel.

As the world demands more diesel, more gasoline components are produced as well, beyond what is actually required to satisfy the global gasoline demand. As a result, the spread between diesel and gasoline prices has been widening significantly. A refiner earns enough on the diesel produced to allow margins on gasoline to fall and still maintain profitability.

\subsubsection{Approach}

Our analysis aims to identify how much of the widening price spread between diesel and gasoline was driven by ethanol (versus diesel demand), and how that effect could increase at higher levels of ethanol blending. We analyzed the gasoline supply shift driven by diesel demand (i.e. fossil gasoline produced as a complementary product of diesel) and the demand shift driven by ethanol in the period 2005-2008, attributing the appropriate share to each driver. Because gasoline and diesel volumes and prices are set on a global basis, we looked at the global impact, assuming the global price changes would be reflected in the U.S. market.

34 Diesel and gasoline components are both outputs of the refinery distillation tower that processes the original crude oil. 


\subsubsection{Findings}

Since 2005, global diesel demand has grown by 1.2 million barrels per day, one and a half times faster than the global gasoline demand, which increased 0.8 million barrels per day over the same time period. At the same time, increased ethanol blending further reduced the demand for fossil gasoline by adding the equivalent of 0.44 million barrels of gasoline per day to the supply, just over half of which was associated with consumption in the United States. As a result, global fossil gasoline demand grew by less than 0.4 million barrels per day since 2005, under one third the increase of diesel demand of 1.2 million barrels per day.

As refiners expanded production capacity to meet the rapidly growing diesel demand since 2005, they simultaneously increased production capacity for gasoline components (including naphtha, which is a blendstock for fossil gasoline, but can also be used as a fuel and as a petrochemical feedstock). In order to cope with this imbalanced demand growth, producers adjusted their refineries to make more diesel and less gasoline components from the same amount of crude oil. These adjustments raised the average output ratio of diesel to gasoline components (including naphtha) from approximately $42 \%$ in 2000 to more than $46 \%$ in 2005 (Exhibit 13). In the same period, the ratio of diesel to finished gasoline (including only the naphtha that was eventually consumed as gasoline) increased from about $54 \%$ to $60 \%$. By 2005 , however, refiners had exhausted most of their low-cost adjustment options and increasing the output ratio of diesel to gasoline components further would require significant capital investments (hence the very limited increase in that ratio since 2005 in Exhibit 13). Since 2005 , refineries have increased their diesel production primarily by processing more crude oil through less complex, marginal refining capacity and by beginning to make investments in diesel-focused refining capacity. ${ }^{35}$ As we will discuss later, refiners further aligned their finished gasoline production with gasoline demand, by diverting naphtha from the gasoline pool to a secondary use - hence the further increase in diesel-to-finished gasoline ratio in Exhibit 13, while the actual ratio between diesel and gasoline components (including naphtha) increased only slightly.

Refineries have needed to add an additional 1.2 million barrels per day of diesel output since 2005 in order to meet the diesel demand growth discussed above. Given the $60 \%$ diesel-tofinished gasoline output ratio in 2005 (after refineries had already adjusted their existing capacity to produce as much diesel as possible), refiners would have added 1.9 million barrels per day of fossil gasoline supply capacity, at a time when the actual demand increase has been less than 0.4 million barrels per day.

35 Specifically hydrocracker capacity, which allows to further crack the gasoil into lighter products, including diesel. 


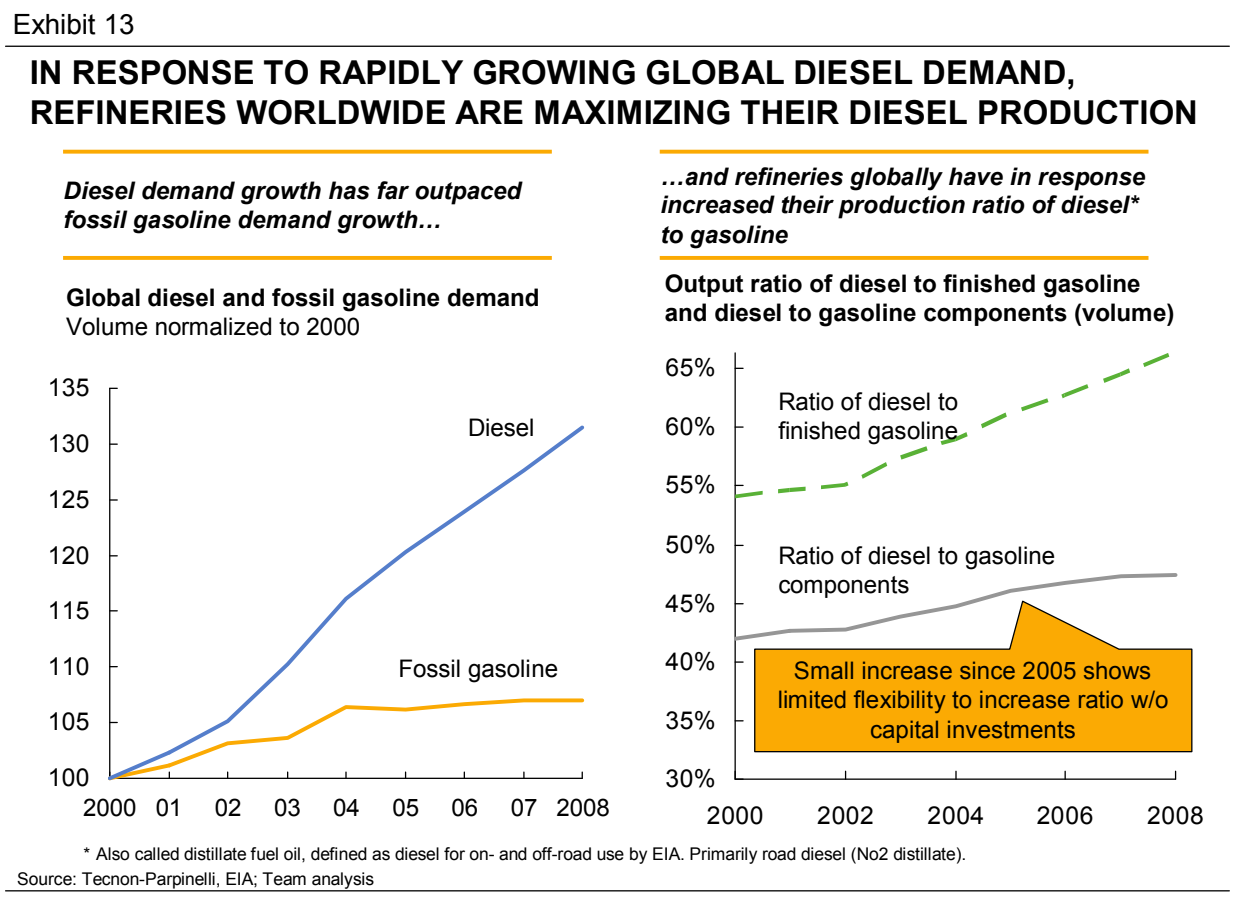

Figure 13. In response to rapidly growing global diesel demand, refineries worldwide are maximizing their diesel production

Exhibit 14 graphically depicts the dynamics described above. The dotted line shows the global demand for gasoline, which has grown 0.8 million barrels per day since 2005. The remainder of the chart shows the sources of incremental gasoline supply capacity. Because of the impact of ethanol, fossil gasoline (orange section) only supplies a portion of the total gasoline demand, the remainder is provided by ethanol (green section). However, the increased diesel demand creates incremental supply capacity, due to increased production required to meet global diesel demand (blue section). Once the aggregate supply capacity exceeds the global demand, there is an oversupply situation and gasoline prices will face downward pressures. This is what has driven the spread between gasoline and diesel. Growing global demand for diesel has driven the diesel price up, while increased oversupply capacity for gasoline has driven the price down. Because any one component on Exhibit 13 can push the gasoline capacity above the global demand, we allocated the impact based on the relative size of the contribution.

Based on this analysis, about 77 percent of the fossil gasoline overcapacity can be attributed to fossil gasoline ${ }^{36}$ supply additions associated with strong demand for diesel. The remaining 23 percent of the effect is a result of increased ethanol blending - 14 percent from U.S. ethanol and 9 percent from the rest of the world, primarily Brazil. Out of the 14 percent contribution of U.S. ethanol to this relative gasoline overcapacity situation, 11 percent is a result of ethanol displacing fossil gasoline demand. The remaining 3 percent (represented by

36 Including naphtha. 
the green wedge above the gasoline demand line in Exhibit 14) is a result of increased fossil gasoline supply capacity due to the yield effect explained in Section 2.4 of this report. ${ }^{37}$

Instead of overproducing gasoline, refiners have been able to largely prevent a physical build-up of gasoline inventories by diverting naphtha (a gasoline component) from the fossil gasoline pool, using it instead as fuel and chemical feedstock, thereby eliminating about 70 percent of the gasoline oversupply (the volume above the gasoline demand line in Exhibit 14).

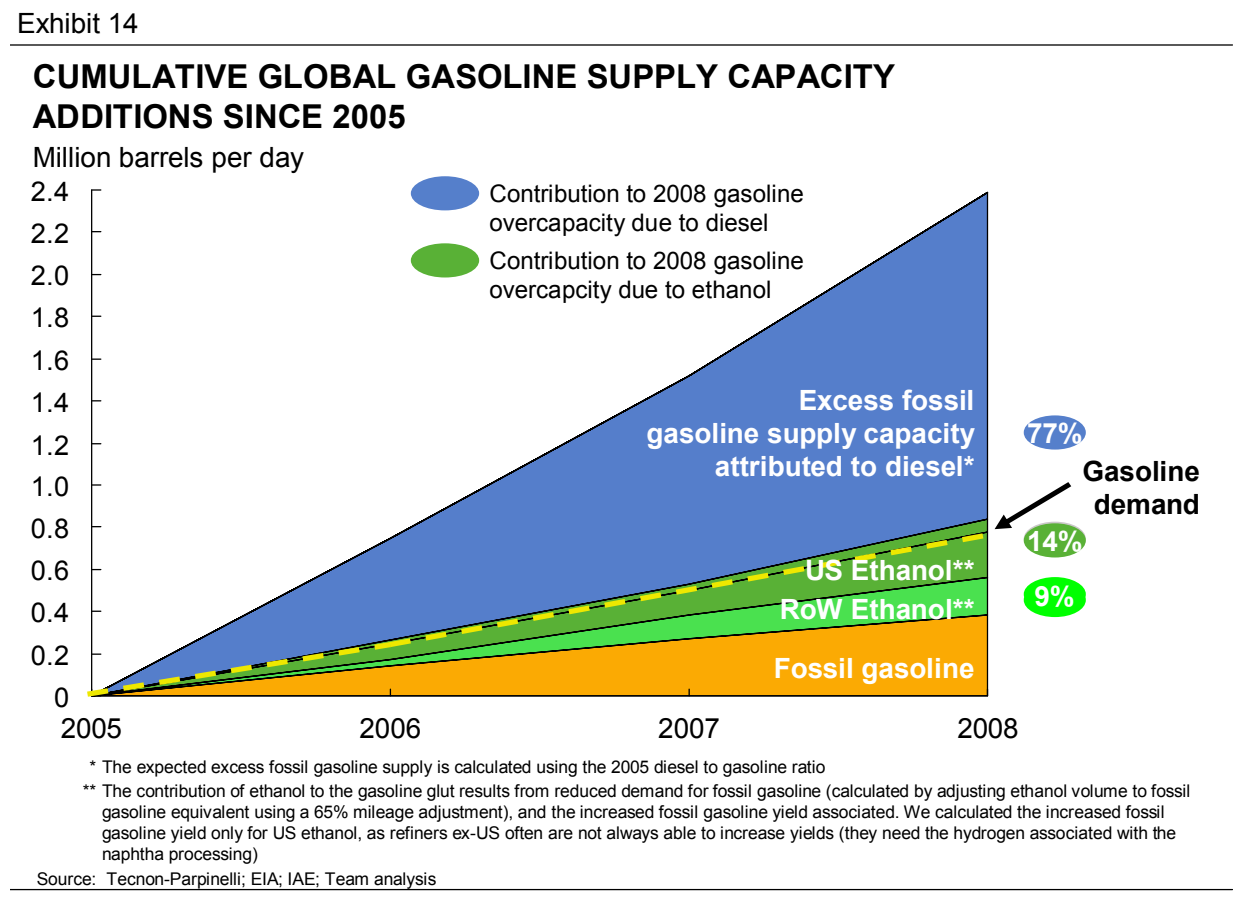

Figure 14. Cumulative global gasoline supply capacity additions since 2005

In addition, some refineries have increased their diesel-to-gasoline output ratios through significant investments in diesel production capacity and operational changes, ${ }^{38}$ eliminating the remaining 30 percent of the oversupply. The relative impact of the two approaches can be seen in Exhibit 13. Indeed, the ratio of diesel to finished gasoline output has increased significantly as naphtha was diverted away from the gasoline pool, while the ratio of diesel to gasoline plus naphtha has only slightly increased as the diesel-focused refining capacity additions are only gradually coming on line.

These two actions taken by refineries to balance gasoline supply and demand will only take place with lower gasoline prices - naphtha will only be diverted from the gasoline pool to a

37 The increased yield described in Section 3 includes the cost benefit outlined in Section 3 as well as a volume impact contributing to the gasoline glut.

38 Adding hydro skimming capacity and replacing catalyst in catalytic cracker to make more diesel, and adjusting distillation cut points to maximize distillate production from both the catalytic cracker and the distillate blending. 
secondary use if the gasoline price is low enough, and refineries will only invest in targeted diesel production capacity if the spread between diesel and gasoline prices has reached a level to justify the investment.

Having quantified the contribution of ethanol and diesel to the widening of the spread between diesel and fossil gasoline prices since 2005 (Exhibit 12), we were able to estimate how much ethanol has contributed to lower gasoline prices. In 2008, refineries typically produce three barrels of gasoline for every two barrels of diesel. Given this ratio, if diesel prices went up by $\$ 1$ per barrel, refiners would be able to lower gasoline prices by 66 cents and still break even. In other words, as gasoline prices lower 40 percent, diesel prices go up 60 percent. U.S. ethanol blending has contributed about 14 percent, or $\$ 2.40$, of the $\$ 17$ increase in the diesel to gasoline spread. Taking 40 percent of this as a contribution to lower gasoline prices, and 60 percent as a contribution to higher diesel prices, we estimate it lowered fossil gasoline prices about 2 cents per gallon. ${ }^{39}$ If the United States could move economically to a national average ethanol concentration of $10 \%$, the per-gallon effect would rise to about 4 cents per gallon. For $15 \%$ and $20 \%$ national average ethanol concentrations, the impact would be 5 and 7 cents, respectively.

It is also important to note that this effect is a truly global effect. Hence, ethanol blending in the U.S. does not just lower fossil gasoline prices in the U.S. but globally, through its contribution to the global gasoline oversupply, in the same way that diesel demand in emerging economies contributes to the rise of U.S. diesel prices.

39 Price differential of $\$ 2.40$ per barrel (42 gallons) attributed to ethanol blending, with effect calibrated to the relative 2008 refinery output of diesel and gasoline (assuming that diesel and gasoline are the primary drivers of refinery pricing). We used the average 2008 spread during first three quarters of 2008 (\$18) and subtracted the $\$ 1$ historical average. Note that we did not subtract the reduction in fossil gasoline price due to the yield effect from the spread between diesel and fossil gasoline prices. Indeed, the yield effect lowers both diesel and fossil gasoline prices, and thus does not impact the spread between diesel and fossil gasoline prices. 


\section{Moderating Crude Oil Prices in the Long Term}

Ethanol blending could play an even more significant role over the longer term by moderating crude oil prices, with a resulting impact on gasoline prices far greater than the 18 to 63 cents per gallon represented by the highest blending level discussed so far.

In recent years, ethanol has been the largest source of additions to the global fuel supply outside of OPEC. In 2008, the United States alone will consume close to 9 billion gallons of ethanol (over 50 percent of global bio-ethanol consumption), displacing 0.4 million barrels of fossil gasoline per day.

However, today's tight diesel supply-demand balance prevents the displaced gasoline from translating into reduced crude oil consumption. Over time, demand growth for fossil diesel may start to slow due to a variety of factors, potentially including a slowing of the global economy, reductions in diesel subsidies in countries like China and India, reduced diesel consumption by drivers in response to record high prices, substitution of natural gas for distillate at power plants, a decline in emergency diesel back-up generation, and increasing biodiesel output. At that point, if gasoline is once again a driver of crude oil demand, lower gasoline demand brought about by ethanol blending should start to directly reduce demand for crude oil.

Refiners worldwide have made significant investments to increase the diesel-to-gasoline output ratio at their refineries, a first step toward easing the pressure on diesel market. Since 2005, diesel-focused refining capacity has grown at twice the rate of other types of refining units. ${ }^{40}$ These adaptations will further help ethanol to displace crude: as ethanol blending increases, refiners will use the increased flexibility to increase diesel and reduce gasoline output per barrel of crude oil, allowing crude oil demand to soften while maintaining diesel output. By displacing up to 1.4 million barrels of crude oil per day when blended to the level of 20-percent of U.S. demand, ethanol would help to restore a critical buffer of spare crude oil production capacity, which could help drive down the crude oil prices, much in the same way that erosion of the buffer has pushed crude oil prices up well above the fundamental marginal production costs over the past few years. Furthermore, ethanol could help to eliminate the need for the most expensive sources of crude oil supply.

The economic benefits of lower crude oil prices could far outweigh the short-term benefit discussed above. By reducing crude oil prices, ethanol would not only lower gasoline prices, but also prices of other petroleum based products, such as jet fuel and diesel. However, this effect is as much more uncertain than the effects we have described in Chapter 2, specifically given OPEC's ability to support prices by reducing crude oil supply.

40 Since 2005, global hydro-cracking capacity has grown at 6 percent year on year, while coking and catalytic cracking capacity have grown at 3 percent and 1 percent, respectively. 


\section{Appendix A: Additional Exhibits}

Exhibit A

OVERVIEW OF END-TO-END GASOLINE PRODUCTION IN U.S.

2008, Million barrels per day

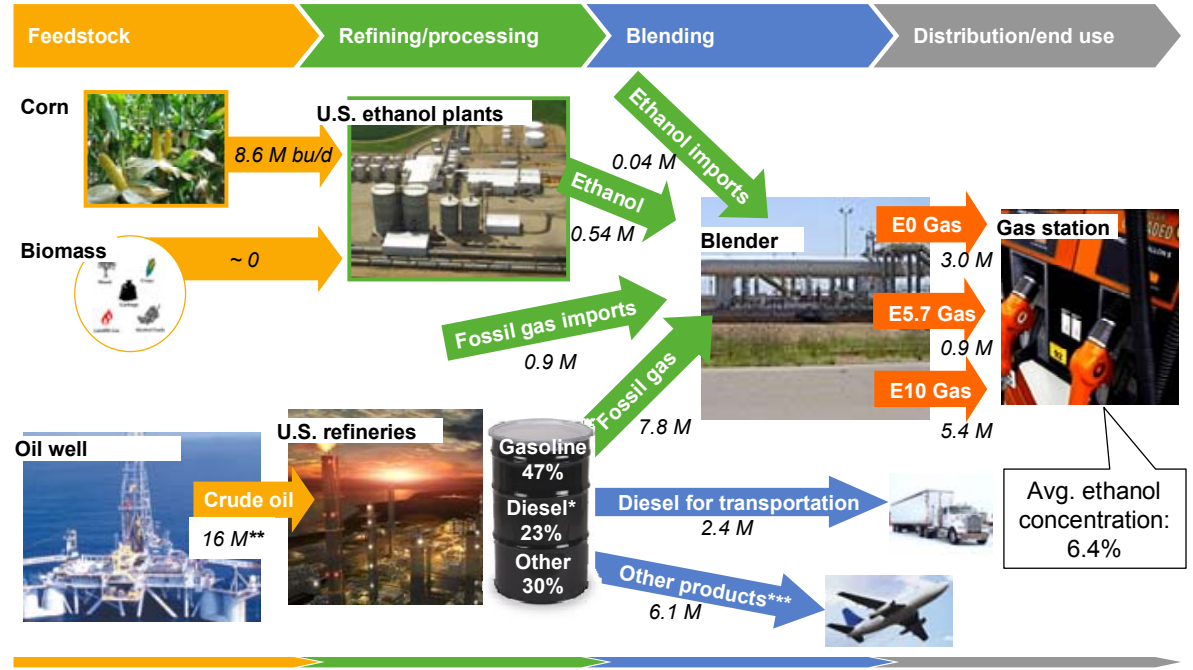

* Also called Distillate Fuel oil, defined as diesel for on- and off-road use by EIA. We assume $65 \%$ of distillate fuel oil is diesel for transportation

${ }_{\star \star *}^{*}$ Not equal to sum of outputs, as there is a refinery processing gain
Includes distillate oil used for heating and other off-road uses Source: EIA, Team analysis

Figure A. Overview of end-to-end gasoline production in U.S.

Exhibit B

\section{BROADER ECONOMIC IMPACT OF ETHANOL BLENDING}

\begin{tabular}{l}
$\begin{array}{l}\text { Effect on retail gasoline price at different volumes of ethanol blending } \\
\$ / \text { Gallon }\end{array}$ \\
\cline { 2 - 5 }
\end{tabular}

1 Based on average U.S. retail gasoline price on October 17, 2008; 2 Based on forecasted U.S. gasoline demand of 17.22 quadrilion BTU in 2008 3 Does include subsidies; 4 Assuming 205 million drivers in US; 5 Based on U.S. population of 302 million Source: EIA; AEO 2008; U.S. DOT; Team analysis

Figure B. Broader economic impact of ethanol blending 


\section{Appendix B: Ethanol pricing mechanisms and the substitution effect}

In efficient markets with balanced supply and demand, the ethanol price will be set by the value that the ethanol has for the refiner when blended in gasoline (the "gasoline blend value"). The gasoline blend value of a gallon of ethanol is equal to the price that the blender would have to pay for a gallon of fossil gasoline plus the value of the blending credit, corrected for the lower mileage of ethanol whenever the blender is not able to price blended gasoline at the same level as unblended. The latter would happen whenever drivers can choose between blended and non-blended gasoline, and are aware of the mileage loss of the blended gasoline compared to the unblended gasoline.

In such a world where ethanol is priced at its gasoline blend value, blending ethanol will not lower the mileage-adjusted price of gasoline, and hence there would be no substitution effect in the strict sense of the word. However, whenever the gasoline blend value pricing mechanism applies, ethanol would be lowering the price of fossil gasoline in another way. The price of fossil gasoline and ethanol would converge at blend value parity as they are substitutes $^{41}$ : as long as the gasoline blend value of ethanol is above its marginal production cost, ethanol producers will increase capacity, which will lead fossil gasoline prices to drop towards ethanol marginal production cost (at the same time, ethanol marginal production costs may increase as production capacity expands).

However, in today's environment, the price of ethanol is not set based on its gasoline blend value due to short term infrastructure constraints that have led to a domestic "over-supply" of ethanol. This supply excess drives ethanol to marginal production economics, instead of gasoline blend value parity, and thus a lower price. Hence, we observe the substitution effect that we have assessed in Section 2.1.

Investments underway today in infrastructure will eventually cause the price of ethanol and gasoline to converge at blend value parity, and the substitution effect will be replaced by a "convergence" effect, as described above. The impact of this convergence effect would be difficult to measure, and could potentially be smaller than the substitution effect seen today under the marginal cost pricing mechanism for ethanol. ${ }^{42}$

$41 \mathrm{Up}$ to the $10 \%$ limit allowed under currently approved gasoline blending formulas. Substantial automotive and infrastructure investments may be required for blending beyond this $10 \%$ limit. Ethanol could be trading at a discount to fossil gasoline, if drivers knew when the gasoline at the pump contains ethanol, have the choice to buy gasoline with or without ethanol, and take the lower mileage of ethanol into account in their purchasing decisions.

42 Note that this convergence effect differs from the Fossil Gasoline Oversupply effect described in Section 2.6. The Fossil Gasoline Oversupply effect estimates the impact of decreased fossil gasoline demand on the fossil gasoline price based on fossil gasoline supply and demand economics, and is not linked to the ethanol production price. The convergence effect on the other hand estimates the impact of adding a lower cost, plentiful source of gasoline, based on substitution economics. 


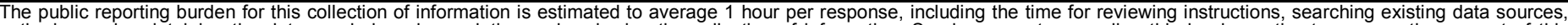

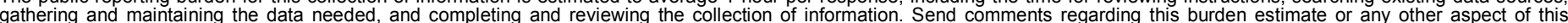

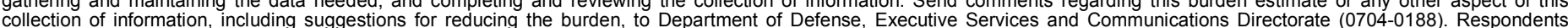

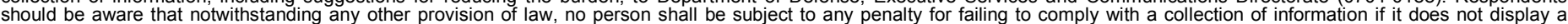

should be aware that notwithstanding

PLEASE DO NOT RETURN YOUR FORM TO THE ABOVE ORGANIZATION.

November 2008

Subcontract Report

4. TITLE AND SUBTITLE

The Impact of Ethanol Blending on U.S. Gasoline Prices

5a. CONTRACT NUMBER

DE-AC36-08-G028308

5b. GRANT NUMBER

5c. PROGRAM ELEMENT NUMBER

6. AUTHOR(S)

Prepared under Subcontract Number KACX-8-88316-01

5d. PROJECT NUMBER

NREL/SR-670-44517

5e. TASK NUMBER

BB077515

5f. WORK UNIT NUMBER

\section{PERFORMING ORGANIZATION NAME(S) AND ADDRESS(ES)}

Prepared under Subcontract Number KACX-8-88316-01
8. PERFORMING ORGANIZATION REPORT NUMBER
KACX-8-88316-01

9. SPONSORING/MONITORING AGENCY NAME(S) AND ADDRESS(ES)

National Renewable Energy Laboratory

1617 Cole Blvd.

Golden, CO 80401-3393

10. SPONSOR/MONITOR'S ACRONYM(S) NREL

11. SPONSORING/MONITORING AGENCY REPORT NUMBER NREL/SR-670-44517

12. DISTRIBUTION AVAILABILITY STATEMENT

National Technical Information Service

U.S. Department of Commerce

5285 Port Royal Road

Springfield, VA 22161

13. SUPPLEMENTARY NOTES

NREL Technical Monitor: Bill Babiuch

14. ABSTRACT (Maximum 200 Words)

This study assesses the impact of ethanol blending on gasoline prices in the US today and the potential impact of ethanol on gasoline prices at higher blending concentrations.

\section{SUBJECT TERMS}

ethanol; gasoline; fuel prices

\begin{tabular}{l} 
16. SECURITY CLASSIFICATION OF: \\
\begin{tabular}{|l|l|l|}
\hline a. REPORT & b. ABSTRACT & c. THIS PAGE \\
Unclassified & Unclassified & Unclassified \\
& & \\
\hline
\end{tabular} \\
\hline
\end{tabular}

\begin{tabular}{l|l} 
17. $\begin{array}{l}\text { LIMITATION } \\
\text { OF ABSTRACT }\end{array}$ & $\begin{array}{l}\text { 18. } \\
\text { NUMBER } \\
\text { OF PAGES }\end{array}$ \\
UL & \\
&
\end{tabular}

19a. NAME OF RESPONSIBLE PERSON

19b. TELEPHONE NUMBER (Include area code) 